Article

\title{
Suppression of External NADPH Dehydrogenase-NDB1 in Arabidopsis thaliana Confers Improved Tolerance to Ammonium Toxicity via Efficient Glutathione/Redox Metabolism
}

\author{
Anna Podgórska ${ }^{1, *}$, Monika Ostaszewska-Bugajska ${ }^{1}{ }^{10}$, Klaudia Borysiuk $^{1}$, Agata Tarnowska ${ }^{1}$, \\ Monika Jakubiak ${ }^{1}$, Maria Burian ${ }^{1}$, Allan G. Rasmusson ${ }^{2}$ and Bożena Szal 1,* ${ }^{\mathbb{D}}$ \\ 1 Institute of Experimental Plant Biology and Biotechnology, Faculty of Biology, University of Warsaw, \\ I. Miecznikowa 1, 02-096 Warsaw, Poland; m.ostaszewska@biol.uw.edu.pl (M.O.-B.); \\ k.borysiuk@biol.uw.edu.pl (K.B.); atarnowska@biol.uw.edu.pl (A.T.); \\ monika.jakubiak@student.uw.edu.pl (M.J.); mburian@biol.uw.edu.pl (M.B.) \\ 2 Department of Biology, Lund University, Sölvegatan 35B, SE-223 62 Lund, Sweden; \\ allan.rasmusson@biol.lu.se \\ * Correspondence: apodgorski@biol.uw.edu.pl (A.P.); szal@biol.uw.edu.pl (B.S.); \\ Tel.: +48-22-55-43-009 (A.P.); +48-22-55-43-005 (B.S.)
}

Received: 17 April 2018; Accepted: 2 May 2018; Published: 9 May 2018

\begin{abstract}
Environmental stresses, including ammonium $\left(\mathrm{NH}_{4}{ }^{+}\right)$nourishment, can damage key mitochondrial components through the production of surplus reactive oxygen species (ROS) in the mitochondrial electron transport chain. However, alternative electron pathways are significant for efficient reductant dissipation in mitochondria during ammonium nutrition. The aim of this study was to define the role of external NADPH-dehydrogenase (NDB1) during oxidative metabolism of $\mathrm{NH}_{4}{ }^{+}$-fed plants. Most plant species grown with $\mathrm{NH}_{4}{ }^{+}$as the sole nitrogen source experience a condition known as "ammonium toxicity syndrome". Surprisingly, transgenic Arabidopsis thaliana plants suppressing $\mathrm{NDB1}$ were more resistant to $\mathrm{NH}_{4}{ }^{+}$treatment. The $\mathrm{NDB1}$ knock-down line was characterized by milder oxidative stress symptoms in plant tissues when supplied with $\mathrm{NH}_{4}{ }^{+}$. Mitochondrial ROS accumulation, in particular, was attenuated in the NDB1 knock-down plants during $\mathrm{NH}_{4}{ }^{+}$treatment. Enhanced antioxidant defense, primarily concerning the glutathione pool, may prevent $\mathrm{ROS}$ accumulation in $\mathrm{NH}_{4}{ }^{+}$-grown NDB1-suppressing plants. We found that induction of glutathione peroxidase-like enzymes and peroxiredoxins in the NDB1-surpressing line contributed to lower ammonium-toxicity stress. The major conclusion of this study was that NDB1 suppression in plants confers tolerance to changes in redox homeostasis that occur in response to prolonged ammonium nutrition, causing cross tolerance among plants.
\end{abstract}

Keywords: ammonium toxicity; external type II NADPH dehydrogenase; glutathione metabolism; reactive oxygen species; redox homeostasis

\section{Introduction}

Cellular oxidation-reduction status functions as an integrator of subcellular metabolism and responds to signals from the external environment [1-3]. NADP $(\mathrm{H})$ and $\mathrm{NAD}(\mathrm{H})$ mediate the flow of reductive power between cellular processes [4], and $\mathrm{NAD}(\mathrm{P}) \mathrm{H}$ can be oxidized by the mitochondrial electron transport chain (mtETC), located in the inner mitochondrial membrane. In plants, mtETC is composed of four multi-subunit complexes: complex I (NADH dehydrogenase), complex II (succinate dehydrogenase), complex III (cytochrome $c$ reductase), and complex IV (cytochrome $c$ oxidase). 
Plant mitochondria also possess unique electron routes that can bypass the pathway from complexes I or II to complex IV. These additional electron pathways include external and internal type II dehydrogenases (NDex and NDin, respectively) and the alternative oxidase (AOX) [5,6]. NAD(P)H dehydrogenases are encoded by three gene families (NDA, NDB and NDC). NDex enzymes encoded by NDB1 utilize NADPH, whereas the enzymes encoded by NDB2, NDB3, and NDB4 utilize NADH; NDB1 and NDB2 isoforms are also $\mathrm{Ca}^{2+}$-dependent or $\mathrm{Ca}^{2+}$-stimulated [6-8]. The NDin isoforms NDA1, NDA2, and NDC1 utilize NADH, while the NDC1 isoform may also utilize NADPH. AOX genes belong to two subfamilies, which in Arabidopsis are composed of AOX1a-d and AOX2 [9].

The path of electrons from complex I through ubiquinone to complexes III and IV (cytochrome pathway) couples the oxidation of reductants to the reduction of $\mathrm{O}_{2}$ to $\mathrm{H}_{2} \mathrm{O}$. The accompanying translocation of protons builds an electrochemical proton gradient that drives oxidative phosphorylation by ATP synthase (ATPase) to produce energy-rich ATP molecules. In contrast with the cytochrome pathway, whose activity is under adenylate control, the additional "alternative" routes are not linked to ATP synthesis or controlled by adenylates. This is because the AOX, NDin, and NDex pathways dissipate excess reductants without proton motive force generation. This prevents over-reduction of the ubiquinone pool or hyperpolarization of the mitochondrial membrane potential, which could inhibit respiration. Plant mitochondria play a central role as reductant sinks, regulating cellular redox homeostasis and preventing redox poise in cells $[4,10]$. Although the additional pathways do not contribute to ATP production, their activity is crucial to minimize the production of reactive oxygen species (ROS). Alternative pathway activity is induced when superfluous reductants require oxidation [11,12]. Plant mitochondria can oxidize NAD $(\mathrm{P}) \mathrm{H}$ from the matrix via complex I or via NDin, and can also oxidize cytosolic $\mathrm{NAD}(\mathrm{P}) \mathrm{H}$ present in the intermembrane space via NDex activity. NDex and NDin have low substrate affinity for $\mathrm{NAD}(\mathrm{P}) \mathrm{H}$ [13] and may be important when excessive reducing power must be oxidized [14]. Whereas, the AOX pathway is important for preventing over-reduction in chloroplasts and to balance redox partitioning during photosynthesis, photorespiration, and respiration [12,15]. Research has indicated the importance of NDin and NDex enzymes in regulating mitochondrial and cytosolic reductant pools. In particular, two Arabidopsis RNA interference (RNAi) lines, suppressing the NDB1 gene for external $\mathrm{Ca}^{2+}$-dependent NADPH oxidation by $90 \%$, have highly similar effects on cellular NADP(H) homeostasis and consequentially on growth rate, respiratory metabolism and defense signaling, as shown by metabolome, transcriptome and flux analysis [16].

A disruption in cellular redox homeostasis, which might occur under stress conditions, is deleterious to plant cells because the production of ROS can be dramatically enhanced $[17,18]$. In plant tissues, ROS are formed by the inevitable leakage of electrons to $\mathrm{O}_{2}$ from the electron transport chains of chloroplasts, $\mathrm{mtETC}$, or as a by-product of metabolic pathways, which may be localized in cellular compartments such as peroxisomes. ROS can damage membranes, proteins, and nucleic acids; inhibit enzymes; and even induce programmed cell death in plants [19]. When ROS production is not effectively balanced by scavenging mechanisms, oxidative stress may occur.

To buffer the toxic effects of ROS, plants have developed several antioxidative systems [20]. The major plant low-mass antioxidants include glutathione and ascorbate, which are present in all cellular compartments. The production of ascorbate (the reduced form AsA) in plants is associated with the $\mathrm{mtETC}$, i.e., the last step of synthesis is catalyzed by L-galactono- $\gamma$-lactone dehydrogenase, an enzyme attached to complex I [21]. The biosynthesis of glutathione, a tripeptide, requires two enzyme-mediated steps, as characterized in Arabidopsis. The enzymes are glutamate-cysteine ligase (GSH1), which is localized in plastids, and glutathione synthetase (GSH2), which is found in plastids and in the cytosol [22,23].

Glutathione is the most abundant non-protein thiol in cells and its nucleophilic activity is exploited in several stress response pathways to detoxify ROS [23,24]. Reduced glutathione (GSH) can directly reduce all kinds of $\operatorname{ROS}\left({ }^{1} \mathrm{O}_{2}, \mathrm{O}_{2} \cdot{ }^{-}, \mathrm{HO} \cdot, \mathrm{H}_{2} \mathrm{O}_{2}\right)$, while itself being oxidized and forming a disulfide form (GSSG). Moreover, GSH can form disulfides with Cys-residues in 
proteins (S-glutathionylation), protecting them from irreversible oxidation and regulating their activity [25]. Glutathione also has a critical function as an electron donor in other enzymatic detoxification systems. In the ascorbate-glutathione cycle (composed of the enzymes ascorbate peroxidase (APX), dehydroascorbate (DHA) reductase (DHAR), monodehydroascorbate reductase (MDHAR), and glutathione reductase (GR)), APX is ultimately responsible for the decomposition of $\mathrm{H}_{2} \mathrm{O}_{2}$ [26]. The ascorbate-glutathione cycle depends on three redox couples: AsA/DHA, GSH/GSSG, and $\mathrm{NAD}(\mathrm{P}) \mathrm{H} / \mathrm{NAD}(\mathrm{P})$, the latter providing the reductant for the former two. In the process of ROS elimination, the network of glutathione peroxidase-like enzymes (GPX), peroxiredoxins (Prx), thioredoxins (TRX) and glutaredoxins (Grx), play an important role [27]. Briefly, GPX and Prx, in their catalytic activity, reduce $\mathrm{H}_{2} \mathrm{O}_{2}$ but also show a strong preference for organic hydroperoxides and peroxinitrite. As a result, GPX and Prx can protect the plant cell not only from ROS but also directly from other stress symptoms such as lipid peroxidation. Further, these enzymes are reduced by TRX in a NADPH- or reduced ferredoxin-dependent manner [28]. Grx, however, can reduce disulfide bonds in protein, a process which is dependent on GSH and that regulates the oxidation state of proteins. Overall, glutathione metabolism requires sulfide group reduction, which is essentially achieved by GR activity using electrons from NADPH. Therefore, GR has been proposed to recycle GSH and to regulate the glutathione redox state in cells [23]. Accordingly, GSH and GSSG form a redox couple that mediate the transfer of reducing equivalents from NADPH to ROS. It is well established that glutathione and ascorbate have a redox potential and are involved in the redox regulation of cells $[29,30]$. In recent years, the contribution of these low-mass antioxidants to redox-connected retrograde signaling has been identified.

Changes in redox state can be evaluated in plant tissues using different approaches. The role of mitochondria and chloroplasts in maintaining cellular redox balance has been demonstrated in studies in which the activity of the mtETC was altered using inhibitors [31,32]. Mutants are useful tools for investigating the influence of specific proteins in vivo on redox metabolism in plant cells. Another strategy is to investigate stress conditions affecting the intracellular redox balance. The responses of plants to diverse abiotic and biotic stress factors have been analyzed extensively in recent years. In their natural environment, plants must adapt to fluctuations in the availability of nutrients, including nitrogen; this implies the potential existence of a method of sensing mineral availability and executing a rapid metabolic response [2,33]. Plants can utilize two different inorganic nitrogen sources, mostly in the forms of ammonium $\left(\mathrm{NH}_{4}{ }^{+}\right)$or nitrate $\left(\mathrm{NO}_{3}{ }^{-}\right)$[34]. It has been proposed that the application of $\mathrm{NH}_{4}{ }^{+}$as the sole source of nitrogen affects redox homeostasis in plant cells $[35,36]$. When comparing $\mathrm{NH}_{4}{ }^{+}$with $\mathrm{NO}_{3}{ }^{-}$nutrition, a surplus of reductants may be expected in plant tissues; this is because $\mathrm{NO}_{3}{ }^{-}$must first be reduced to $\mathrm{NH}_{4}{ }^{+}$in a two-step reduction reaction before its incorporation into amino acids. In the first step, $\mathrm{NO}_{3}{ }^{-}$must be reduced to nitrite (using $\mathrm{NADH}$ ) in a reaction catalyzed by cytosolic nitrate reductase (NR), and then to $\mathrm{NH}_{4}{ }^{+}$(using NADPH or reduced ferredoxin) via nitrite reductase (NiR) in the plastids $[37,38]$. In contrast, when $\mathrm{NH}_{4}{ }^{+}$is supplied as the exclusive nitrogen source, thus $\mathrm{NO}_{3}{ }^{-}$reduction is omitted, the consumption of reducing equivalents is lower in the cytosol and chloroplasts. In terms of energy economy, $\mathrm{NH}_{4}{ }^{+}$seems to represent a better source of nitrogen nutrition for plants, as its assimilation requires less energy than $\mathrm{NO}_{3}{ }^{-}[37,39]$. Ammonium nutrition can, however, potentially lead to an accumulation of reductants in these compartments, and consequentially NDex, NDin and AOX enzymes have been observed to be acutely induced by short-term $\mathrm{NH}_{4}{ }^{+}$supply [38]. Nevertheless, plants cultured on $\mathrm{NH}_{4}{ }^{+}$as the sole nitrogen source exhibit symptoms of toxicity (e.g., growth inhibition), commonly referred to as "ammonium syndrome" [40,41]. We have previously shown that an intracellular redox imbalance during $\mathrm{NH}_{4}{ }^{+}$assimilation may lead to oxidative stress in Arabidopsis plant tissues [42]. The increased mtETC activity and possible over-reduction of the mtETC in response to $\mathrm{NH}_{4}{ }^{+}$nutrition can also induce excessive mitochondrial ROS generation. Plant mitochondria have subsequently been identified as the primary source of $\mathrm{ROS}$ during extended $\mathrm{NH}_{4}{ }^{+}$nutrition $[42,43]$. 
Extensive research has been devoted to the identification of the mechanisms behind the causes of $\mathrm{NH}_{4}{ }^{+}$toxicity in plants, as it would be advantageous to minimize the effects of ammonium syndrome as a way to increase crop biomass production [44-46]. Mitochondria-associated metabolic reactions such as respiration may potentially increase nitrogen use efficiency [47-49]. It can therefore be expected that, for the proper functioning of plants grown on $\mathrm{NH}_{4}{ }^{+}$as the sole source of nitrogen, it is important to dissipate excess reducing power arising in the cytosol or chloroplast. Since NDex are the major entry point of cytosolic NAD $(\mathrm{P}) \mathrm{H}$ not used in metabolic reactions, their function may be primarily important during $\mathrm{NH}_{4}{ }^{+}$nutrition. This was also indicated, in our previous study, where the main isoform of additional dehydrogenases elevated under growth on $\mathrm{NH}_{4}{ }^{+}$was NDB1 [42].

The aim of the present study was to investigate the role of the $\mathrm{Ca}^{2+}$-dependent external NADPH dehydrogenase, NDB1, during $\mathrm{NH}_{4}{ }^{+}$nutrition. Transgenic Arabidopsis RNA interference lines suppressing NDB1 [16] were utilized in these studies. In the absence of NDex, an over-reduction of the redox-state might represent a burden for plants during $\mathrm{NH}_{4}{ }^{+}$nutrition. However, NDB1 knock-downs were surprisingly less sensitive to prolonged $\mathrm{NH}_{4}{ }^{+}$nutrition. In this study, we investigated redox/ROS homeostasis in plants grown on different nitrogen sources. It was shown that the improved tolerance to $\mathrm{NH}_{4}{ }^{+}$in NDB1 suppressing plants may be connected to elevated glutathione metabolism, including $S$-glutathionylation of proteins or altered responses of the redox regulatory network.

\section{Results}

NDB1 knock-down plants grown for 8 weeks in hydroponic culture under a short-day photoperiod had a similar rosette size and fresh weight as wild-type (WT) plants grown on the same nitrogen source (Figure 1A,B). Ammonium nutrition caused approximately 90\% growth inhibition in both NDB1 and WT plants (Figure 1B).

A

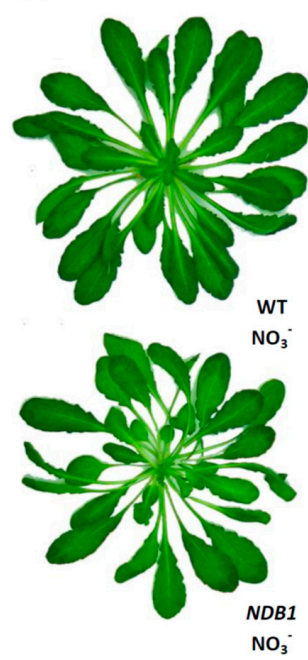

B

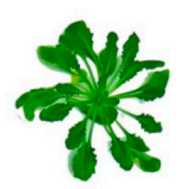

$\mathrm{NH}_{4}^{+}$

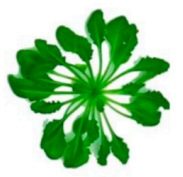

$N D B 1$

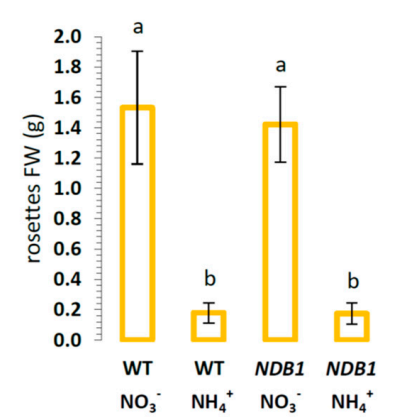

$\begin{array}{llll}\mathrm{NO}_{3} & \mathrm{NH}_{4}^{+} & \mathrm{NO}_{3}{ }^{-} & \mathrm{NH}_{4}^{+}\end{array}$

Figure 1. Phenotype of Arabidopsis thaliana NDB1-suppressing line 1.5 (NDB1) and wild type ecotype Col-0 (WT) after 8 weeks' growth in hydroponic cultures on $5 \mathrm{mM} \mathrm{NO}_{3}{ }^{-}$or $5 \mathrm{mM} \mathrm{NH}_{4}{ }^{+}$as the sole nitrogen source. (A) Visual appearance of representative plants. All images are in the same scale; (B) Fresh weight (FW) of rosettes of WT and NDB1 knock-down plants on respective nitrogen sources. Bars with different letters are statistically different $(p<0.05)$ by ANOVA.

\subsection{Changes in Respiration and Pyridine Nucleotide Status in NDB1 Suppression Plants Cultured on $\mathrm{NO}_{3}{ }^{-}$ or $\mathrm{NH}_{4}^{+}$}

In $\mathrm{NH}_{4}{ }^{+}$-grown plants, excess reductants not used in cytosolic reactions can be oxidized by type II dehydrogenases to prevent over-reduction of the mtETC. In general, ammonium nutrition induced higher total respiration $\left(\mathrm{V}_{\mathrm{t}}\right)$, cytochrome pathway capacity $\left(\mathrm{V}_{\mathrm{cyt}}\right)$, and alternative pathway 
capacity $\left(\mathrm{V}_{\text {alt }}\right)$ in both NDB1 and WT plants (Table 1). Growth on $\mathrm{NH}_{4}{ }^{+}$led to a slightly lower $\mathrm{V}_{\mathrm{t}}$ in NDB1 knock-down than in WT plants (Table 1). However, $\mathrm{V}_{\text {cyt }}$ and $\mathrm{V}_{\text {alt }}$ were similar between NDB1 knock-down and WT plants for each nitrogen treatment (Table 1).

Table 1. Respiratory parameters in NDB1-suppressing and WT Arabidopsis plants grown on $\mathrm{NH}_{4}{ }^{+}$and $\mathrm{NO}_{3}{ }^{-}$(control) as the only source of nitrogen. Values are shown for total respiration $\left(\mathrm{V}_{\mathrm{t}}\right)$, cytochrome pathway capacity $\left(\mathrm{V}_{\mathrm{cyt}}\right)$, and alternative pathway capacity $\left(\mathrm{V}_{\mathrm{alt}}\right)$ in dark-adapted leaves. Results with different letters are statistically different $(p<0.05)$ by ANOVA.

\begin{tabular}{ccccc}
\hline & WT NO $_{3}{ }^{-}$ & WT NH $_{4}{ }^{+}$ & NDB1 NO$_{3}{ }^{-}$ & NDB1 NH \\
\hline & Oxygen consumption $(\mathrm{nmol} \mathrm{O}$ & min $\left.^{-1} \mathrm{~g}^{-1} \mathrm{FW}\right)$ & \\
\hline Total respiration $\left(\mathrm{V}_{\mathrm{t}}\right)$ & $40.54^{\mathrm{a}} \pm 9.93$ & $93.16^{\mathrm{c}} \pm 3.67$ & $41.38^{\mathrm{a}} \pm 5.99$ & $72.92^{\mathrm{b}} \pm 2.96$ \\
$+\mathrm{SHAM}\left(\mathrm{V}_{\text {cyt }}\right)$ & $37.31^{\mathrm{a}} \pm 7.65$ & $66.09^{\mathrm{b}} \pm 6.39$ & $36.46^{\mathrm{a}} \pm 10.84$ & $55.45^{\mathrm{ab}} \pm 4.62$ \\
$+\mathrm{KCN}\left(\mathrm{V}_{\text {alt }}\right)$ & $5.94^{\mathrm{a}} \pm 3.11$ & $38.98^{\mathrm{b}} \pm 10.58$ & $5.82^{\mathrm{a}} \pm 1.38$ & $46.47^{\mathrm{b}} \pm 2.74$ \\
\hline
\end{tabular}

We next examined how silencing of NDB1 affects the redox state of pyridine nucleotides. Under nitrate nutrition in NDB1 knock-down plants, we observed a slightly increased NADPH concentration, similar to that shown in [16]. Overall, however, NDB1 silencing did not significantly perturb the redox state of $\mathrm{NADP}(\mathrm{H})$ in leaves in both growth conditions (Figure 2). The pyridine nucleotide pool was only affected by the applied nitrogen source; ammonium nutrition increased the NADPH content up to four-fold in both genotypes, which resulted in a higher NADPH/NADP ratio (Figure 2).

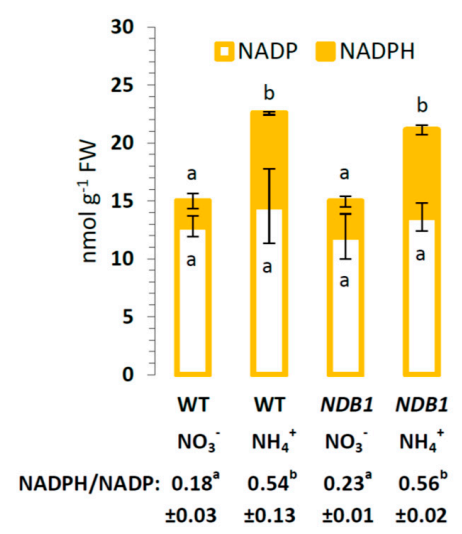

Figure 2. Phosphorylated pyridine nucleotide concentrations in NDB1-suppressing and WT plants growing on $\mathrm{NH}_{4}{ }^{+}$and $\mathrm{NO}_{3}{ }^{-}$(control) as the only source of nitrogen. Bars with different letters are statistically different $(p<0.05)$ by ANOVA.

\subsection{Influence of NDB1 Suppression on ROS Content and Oxidative Damage in Tissues of Plants Fed $\mathrm{NO}_{3}{ }^{-}$ or $\mathrm{NH}_{4}^{+}$}

Altered redox homeostasis in plants may consequently affect ROS production in tissues. In WT plants, the content of $\mathrm{H}_{2} \mathrm{O}_{2}$ was elevated more than $20 \%$ in response to $\mathrm{NH}_{4}{ }^{+}$nutrition. However, in NDB1 knock-downs, which had a similar $\mathrm{H}_{2} \mathrm{O}_{2}$ level as WT plants, $\mathrm{NH}_{4}{ }^{+}$nutrition did not increase tissue $\mathrm{H}_{2} \mathrm{O}_{2}$ content (Figure 3A). In order to identify the source of ROS in leaf cells, the distribution of $\mathrm{H}_{2} \mathrm{O}_{2}$ in mesophyll tissues was visualized by $2^{\prime}, 7^{\prime}$-dichlorodihydrofluorescein diacetate (DCF-DA) fluorescence. The co-localization of DCF-dependent fluorescence with mitochondria (green/red channels) or with chloroplasts (green/far red channels) (Figure 3C) showed the amount of ROS produced in the respective organelles (Figure 3B). Chloroplasts revealed an obvious fluorescent overlap that co-localized in the DCF-dependent fluorescence, showing a Pearson's coefficient higher than 0.7 in all analyzed variants (Figure 3B). The detection rate of co-localization between DCF- 
and mitochondria-dependent fluorescence was the highest in $\mathrm{NH}_{4}{ }^{+}$-exposed WT cells (Figure 3B), which suggests higher mitochondrial ROS production in these organelles. The defect in NDB1 in the mtETC of knock-down plants did not change the degree of DCF-fluorescence as compared with that of mitochondria of WT plants grown on $\mathrm{NO}_{3}{ }^{-}$. However, during the $\mathrm{NH}_{4}{ }^{+}$growth regime, DCF-staining connected to mitochondria was only slightly increased in the NDB1 knock-down (Figure 3B).
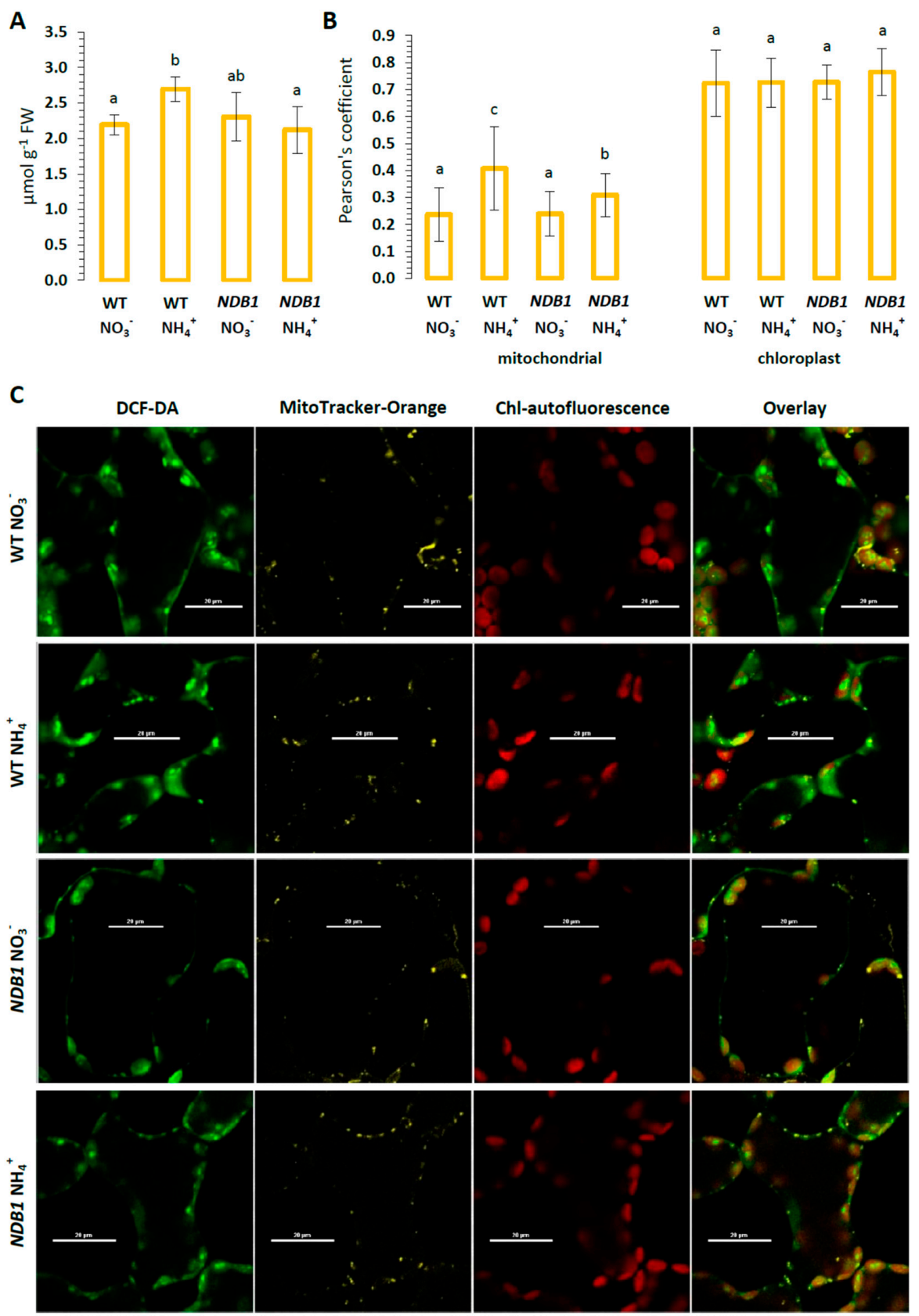

Figure 3. Reactive oxygen species (ROS) in NDB1-suppressed and WT plants growing on $\mathrm{NH}_{4}{ }^{+}$ and $\mathrm{NO}_{3}{ }^{-}$(control) as the only source of nitrogen. (A) Hydrogen peroxide content; (B) sub-cellular ROS distribution in leaf segments. Pearson's co-localization coefficient shows the proportion of DCF-labelling with mitochondria-dependent fluorescence or chlorophyll autofluorescence. Bars with different letters are statistically different $(p<0.05)$ by ANOVA; $(\mathbf{C})$ The mesophyll cells of WT and NDB1 knock-downs were double-labelled with $2^{\prime}, 7^{\prime}$-dichlorodihydrofluorescein diacetate (DCF-DA, Green) and MitoTracker Orange (reduced CM-H $\mathrm{H}_{2}$ TMRos, yellow), and chloroplast autofluorescence (far red) was observed; representative images from four independent biological replicates; scale bar $=20 \mu \mathrm{m}$. 
Since high ROS levels may lead to oxidative modifications of cell components, we estimated malondialdehyde (MDA) content as a marker of peroxidation of membrane lipids, expression of the specific stress response protein up-regulated by oxidative stress (UPOX, [50]), and protein carbonylation level. In WT plants, $\mathrm{NH}_{4}{ }^{+}$nutrition, as compared with $\mathrm{NO}_{3}{ }^{-}$nutrition, led to a $20 \%$ increase in lipid peroxidation (Figure 4A). Lipid peroxidation in NDB1 knock-down plants grown on $\mathrm{NO}_{3}{ }^{-}$was similar to that in WT plants (Figure 4A), but the treatment of NDB1 knock-down plants with $\mathrm{NH}_{4}{ }^{+}$resulted in an $15 \%$ lower MDA content in tissues (Figure $4 \mathrm{~A}$ ).

A

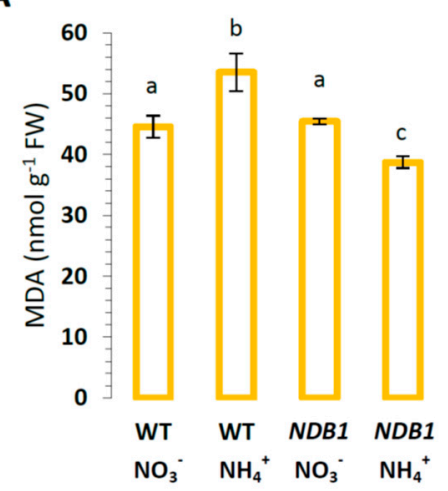

C

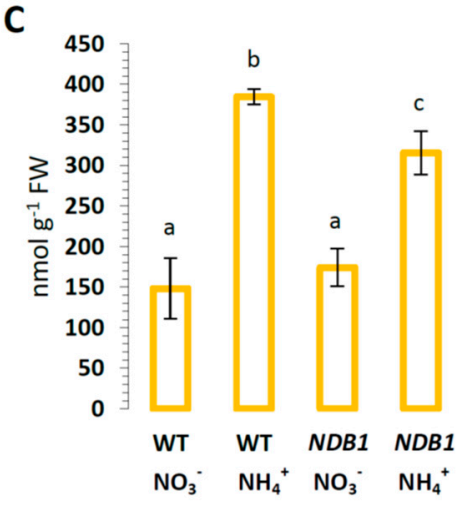

B

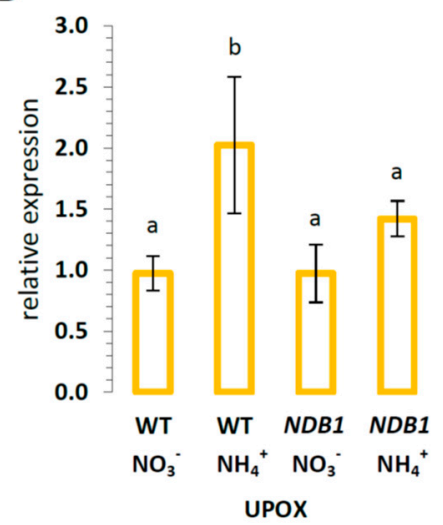

D

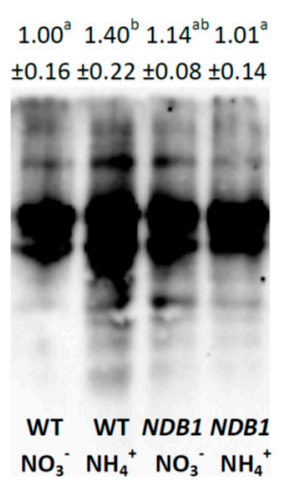

Figure 4. Oxidative stress markers in NDB1-suppressed and WT plants grown on $\mathrm{NH}_{4}^{+}$and $\mathrm{NO}_{3}{ }^{-}$(control) as the only source of nitrogen. (A) Lipid peroxidation estimated in leaves as MDA content; (B) transcript level for mitochondria-localized protein UPOX up-regulated by oxidative stress; (C) concentration of carbonylated proteins; and (D) immunoblot analysis of protein-bound carbonyls. Bars or bands with different letters are statistically different $(p<0.05)$ by ANOVA.

Ammonium nutrition induced a higher UPOX transcript level in WT plants grown on $\mathrm{NO}_{3}{ }^{-}$, but in the NDB1 knock-down line, its expression was similar to that of the control, independent of the nitrogen source (Figure 4B). The level of protein carbonylation was more than 2.5-times higher in WT plants in response to $\mathrm{NH}_{4}{ }^{+}$nutrition (Figure 4C). In NDB1 knock-down plants, which had a similar extent of lipid oxidation to control plants, when grown on $\mathrm{NO}_{3}{ }^{-}$, the content of carbonylated proteins was elevated less than two-fold during $\mathrm{NH}_{4}{ }^{+}$nutrition. The profile of proteins with carbonyl groups was also traced by immunoblotting. Ammonium nutrition induced a strong increase in protein carbonyls in WT plants, being 40\% elevated within the whole protein spectrum (Figure 4D). However, the NDB1 knock-down plants had an unchanged pattern of carbonylated proteins compared with control plants, and this pattern was not further increased by the $\mathrm{NH}_{4}{ }^{+}$treatment.

Overall, our data indicate that unlike WT, NDB1 knock-down plants do not develop major oxidative stress symptoms in response to ammonium nutrition, an effect that may be attributable to efficient antioxidant defense systems. 
2.3. Ascorbate Level and Ascorbate-Related Antioxidant Defense in NDB1 Knock-Down Plants in Response to $\mathrm{NO}_{3}{ }^{-}$or $\mathrm{NH}_{4}{ }^{+}$Nutrition

Ascorbate is a major low-mass antioxidant. The content of AsA was stable in WT and NDB1 knock-down plants during growth on different nitrogen sources (Figure 5A). However, the DHA content decreased in the NDB1 knock-down line during $\mathrm{NO}_{3}{ }^{-}$growth compared with WT, which resulted in an elevated AsA/DHA redox state (Figure 5A). In contrast, during growth on $\mathrm{NH}_{4}{ }^{+}$, an increase in DHA content was detected in the NDB1 knock-downs compared with WT, but the AsA/DHA ratio remained similar to that of WT plants grown on $\mathrm{NH}_{4}{ }^{+}$(Figure 5A). All APX isoforms had similar protein levels in NDB1 knock-downs compared with WT plants and showed high accumulation under ammonium nutrition in both genotypes (Figure 5B). The same trend was observed for MDHAR and DHAR activities, which were similar between NDB1 knock-downs and WT plants and were highly induced under ammonium nutrition (Figure 5C).

A

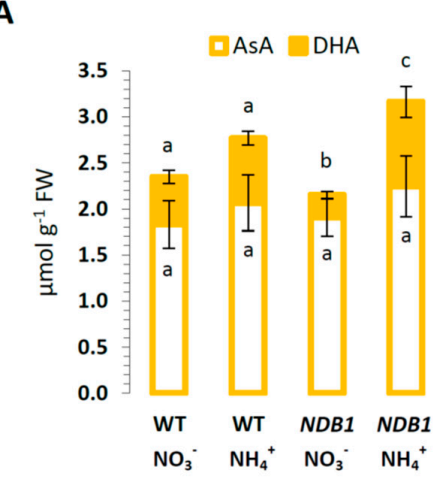

AsA/DHA: $4.25^{\mathrm{a}} \quad 2.50^{\mathrm{b}} \quad 7.22^{\mathrm{c}} \quad 2.10^{\mathrm{b}}$

$\pm 0.33 \pm 0.25 \pm 1.26 \quad \pm 0.24$

\section{C}

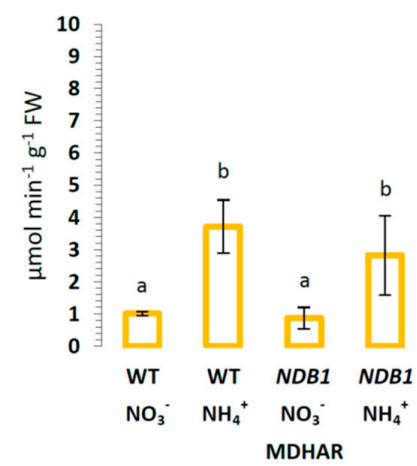

B
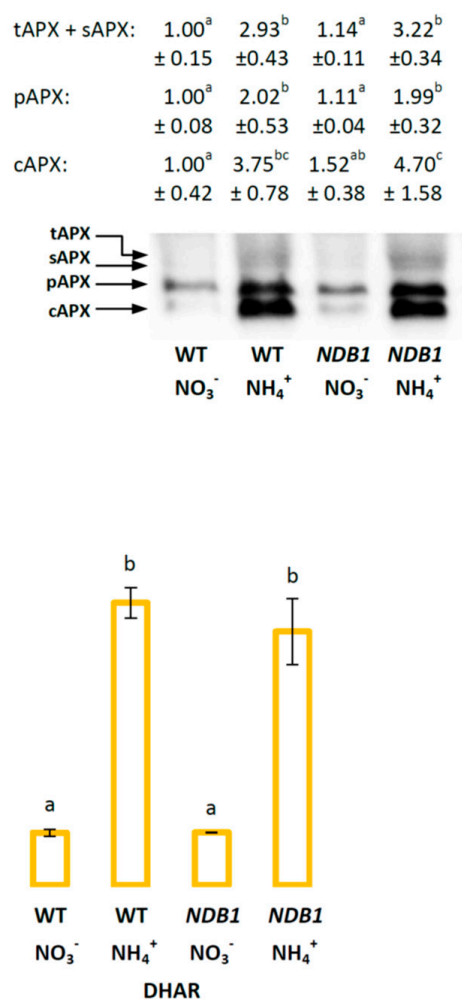

Figure 5. Content of ascorbate and ascorbate-utilizing enzymes in NDB1-suppressing and WT plants grown on $\mathrm{NH}_{4}{ }^{+}$and $\mathrm{NO}_{3}{ }^{-}$(control) as the only source of nitrogen. (A) Concentration of reduced (AsA) and oxidized (DHA) ascorbate and derived AsA/DHA ratio; (B) ascorbate peroxidase (APX) protein levels. Thylakoid (tAPX, $38 \mathrm{kDa}$ ), stromal (sAPX, $33 \mathrm{kDa}$ ); peroxisomal (pAPX, $31 \mathrm{kDa}$ ), and cytoplasmic (cAPX, $25 \mathrm{kDa}$ ) forms of ascorbate peroxidases; (C) monodehydroascorbate reductase (MDHAR) and dehydroascorbate reductase (DHAR) activities. Bars or bands with different letters are statistically different $(p<0.05)$ by ANOVA.

\subsection{Glutathione Metabolism in NDB1 Knock-Down Plants during $\mathrm{NO}_{3}{ }^{-}$or $\mathrm{NH}_{4}{ }^{+}$Growth}

Ammonium nutrition in WT plants resulted in higher levels of GSH and GSSG and a more oxidized GSH/GSSG ratio compared with $\mathrm{NO}_{3}{ }^{-}$-grown plants. During $\mathrm{NO}_{3}{ }^{-}$nutrition, the NDB1 knock-down line also showed increased GSH and GSSG content compared with WT plants and the GSH/GSSG ratio was similar in both genotypes (Figure 6A). When grown on $\mathrm{NH}_{4}{ }^{+}$, the NDB1 
knock-downs had even higher glutathione levels, showing an increase of $90 \%$ in the content of GSH and 50\% in GSSG (Figure 6A). However, the GSH/GSSG ratio was unchanged compared with the $\mathrm{NO}_{3}{ }^{-}$nutrition of NDB1 knock-down plants. As glutathione is considered the major cellular redox buffer, we can conclude from the redox state of the glutathione pool that NDB1 knock-down plants are not adversely affected by modifications in their cellular redox state.

The transcript level of both genes from the glutathione biosynthetic pathway, GSH1 and GSH2, was similar between different nitrogen treatments in WT plants, but in NDB1 knock-down plants, ammonium nutrition stimulated GSH1 and GSH2 expression (Figure 6B), leading to a significantly higher glutathione pool (Figure 6A).

A high rate of glutathione reduction in NDB1 knock-down plants could be explained by the up-regulation of glutathione reductase. We therefore analyzed GR protein levels. Densitometric analysis revealed that GR levels were similar between NDB1 knock-downs and WT plants grown under control conditions (Figure 6C). Ammonium nutrition resulted in a two-fold increase in GR protein in both WT and NDB1 knock-down plants (Figure 6C). To further elucidate the involvement of GR in GSH reduction in $\mathrm{NH}_{4}{ }^{+}$-grown $\mathrm{NDB1}$ knock-down lines, we analyzed the expression of two GR-encoding genes: GR1, which encodes the cytosolic isozyme, and GR2, which encodes an isoform dual-targeted to chloroplasts and mitochondria. In $\mathrm{NDB1}$ knock-down plants grown on $\mathrm{NO}_{3}{ }^{-}$, the transcript level for both genes was similar to that in WT plants (Figure 6D). Interestingly, GR1 and GR2 showed opposite trends of expression between treatments: GR1 was induced while GR2 was suppressed by ammonium nutrition in both genotypes.

A

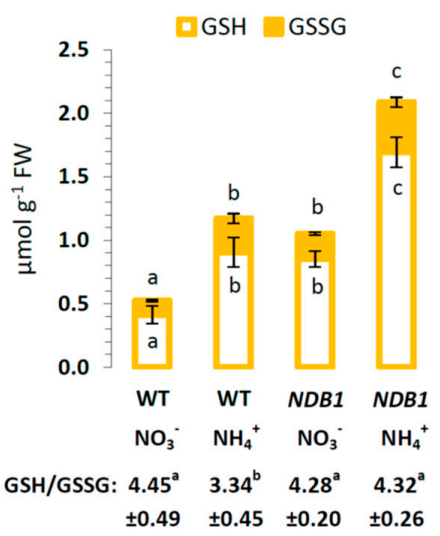

B
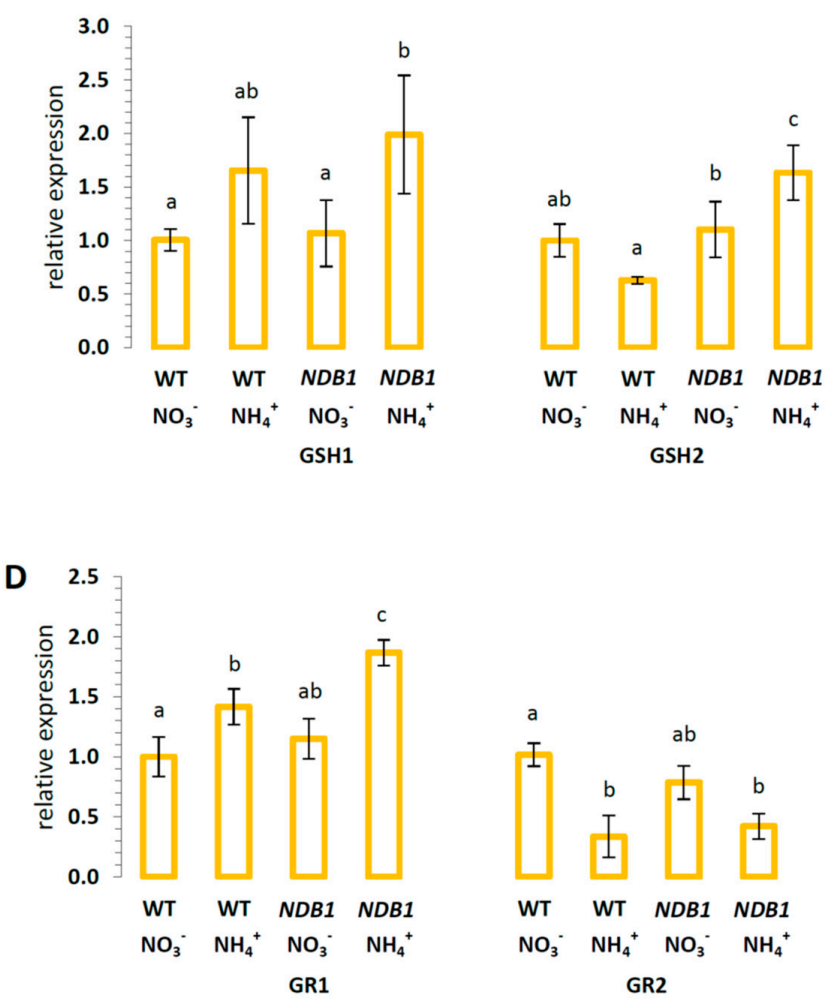

Figure 6. Glutathione contents and glutathione metabolism-related enzymes in NDB1-suppressing and WT plants growing on $\mathrm{NH}_{4}{ }^{+}$and $\mathrm{NO}_{3}{ }^{-}$(control) as the only source of nitrogen. (A) Concentration of reduced (GSH) and oxidized (GSSG) glutathione and derived GSH/GSSG ratio; (B) transcript levels for GSH1 and GSH2; (C) GR protein levels; (D) transcript levels for GR isoforms, GR1 and GR2. Bars or bands with different letters are statistically different $(p<0.05)$ by ANOVA. 
An induction of the glutathione biosynthetic pathway and increase in glutathione content may lead to higher S-glutathionylation of proteins. Therefore, we determined the level of this modification in leaf protein extracts by western blotting with anti-GSH antibodies. Densitometry analysis of the entire blot lane revealed that, in WT plants, ammonium nutrition increased the level of protein S-glutathionylation compared with $\mathrm{NO}_{3}{ }^{-}$nutrition (Figure 7). NDB1 silencing alone had no effect on $S$-glutathionylation, while in knock-down plants under $\mathrm{NH}_{4}{ }^{+}$nutrition, the increase in S-glutathionylation of proteins was even more pronounced than in WT plants (Figure 7).

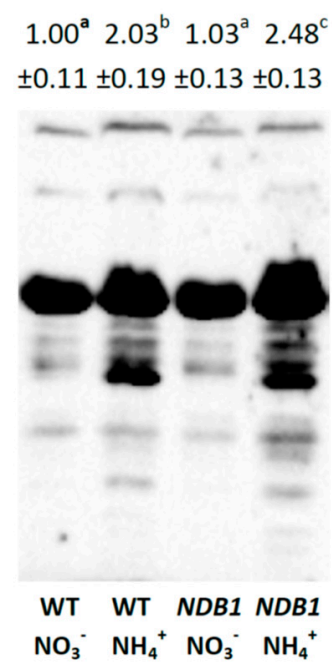

Figure 7. S-glutathionylated protein level in NDB1-suppressing and WT plants grown on $\mathrm{NH}_{4}{ }^{+}$and $\mathrm{NO}_{3}{ }^{-}$(control) as the only source of nitrogen. Bands with different letters are statistically different $(p<0.05)$ by ANOVA.

\subsection{The Effect of NDB1 Suppression on Redox-Related Enzymes in Plants Grown on $\mathrm{NO}_{3}{ }^{-}$or $\mathrm{NH}_{4}{ }^{+}$}

We analyzed the expression profile of different redox related enzymes from the peroxiredoxin, glutathione peroxidase-like, thioredoxin, and glutaredoxin network. In WT plants, chloroplastic isoforms were generally either down-regulated (GPX1, GrxS14, NTRC, TRXx, TRXy2, and 2Cys PrxA) or unchanged (GPX7) in response to $\mathrm{NH}_{4}{ }^{+}$nutrition (Figure $8 \mathrm{~A}, \mathrm{D}, \mathrm{F}, \mathrm{G}$ ). The defect in NDB1 did not alter the expression of most analyzed isoforms in knock-down plants. However, the treatment of NDB1 knock-down plants with $\mathrm{NH}_{4}{ }^{+}$led to an induction of GPX1 and GPX7, while GrxS14, NTRC, TRXx, TRXy2, and 2Cys PrxA remained at a stable level, as in NDB1 knock-down plants grown on $\mathrm{NO}_{3}{ }^{-}$ (Figure 8A,D,F,G). The protein level of the chloroplastic peroxidase PrxQ was unchanged between WT and NDB1 knock-down plants but showed a major increase during $\mathrm{NH}_{4}{ }^{+}$nutrition, especially in the NDB1 knock-down line (Figure 8H). The expression of mitochondrial GPX6 was strongly induced in WT under $\mathrm{NH}_{4}{ }^{+}$nutrition, and was also elevated in $\mathrm{NH}_{4}{ }^{+}$-grown NDB1 knock-down plants (Figure 8C). Mitochondrial PrxIIF was down-regulated in response to $\mathrm{NH}_{4}{ }^{+}$nutrition and in NDB1 knock-down plants (Figure 8E). Ammonium supply to the NDB1 knock-down plants increased the expression of mitochondrial PrxIIF (Figure 8E). Furthermore, the expression of cytosolic PrxIIc was induced in NDB1 knock-down plants when grown on $\mathrm{NH}_{4}{ }^{+}$(Figure 8G). The abundance of cytosolic GPX2 (Figure 8B) and GPX8 (Supplementary Materials Figure S2) transcripts was unchanged throughout. 
A

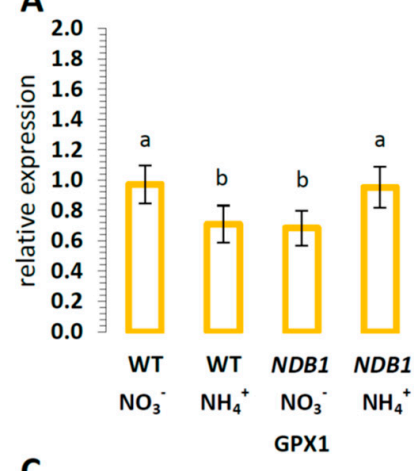

C

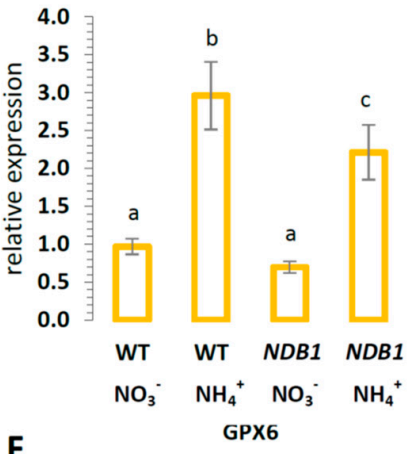

$\mathbf{F}$
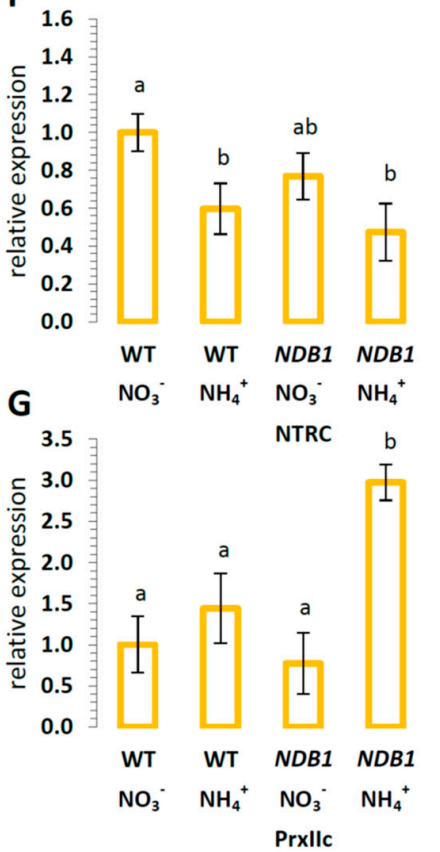

D

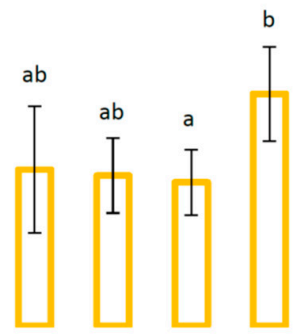

WT WT NDB1 NDB1

$\begin{array}{llll}\mathrm{NO}_{3}{ }^{-} & \mathrm{NH}_{4}{ }^{+} & \mathrm{NO}_{3}{ }^{-} & \mathrm{NH}_{4}{ }^{+}\end{array}$

GPX7
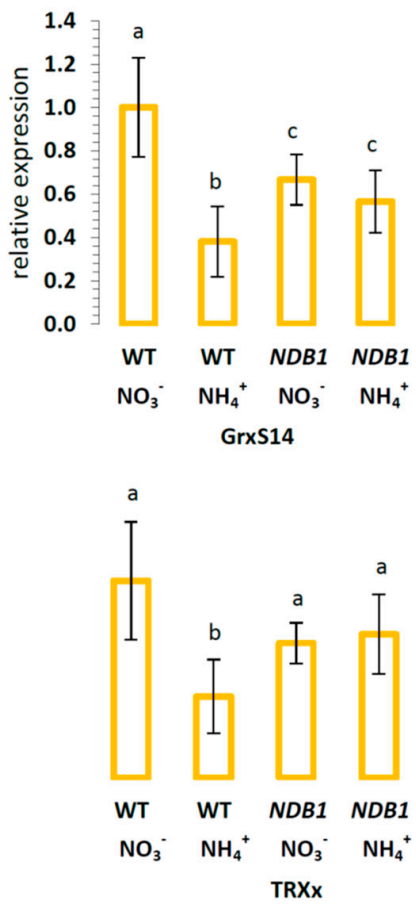

E

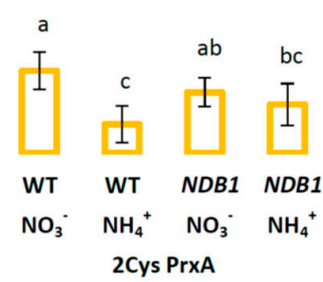

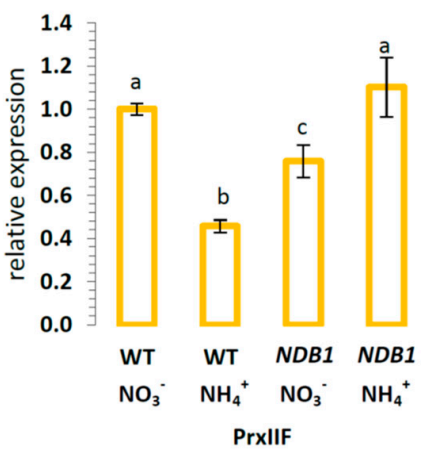
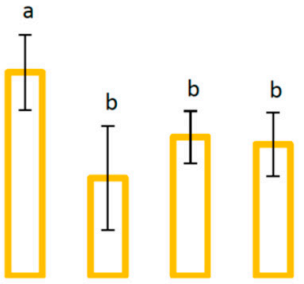

WT WT NDB1 NDB1

$\begin{array}{llll}\mathrm{NO}_{3}{ }^{-} & \mathrm{NH}_{4}^{+} & \mathrm{NO}_{3}^{-} & \mathrm{NH}_{4}^{+}\end{array}$

TRXY2

H

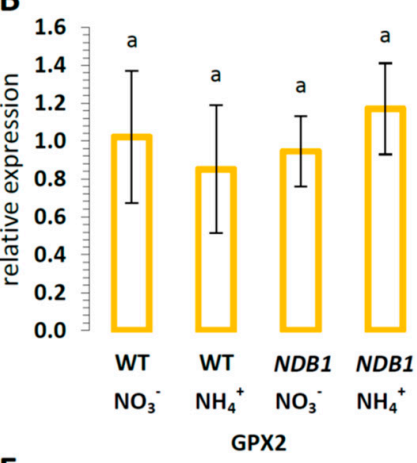

$\begin{array}{llll}1.00^{\mathrm{a}} & 1.73^{\mathrm{b}} & 1.14^{\mathrm{a}} & 2.60^{\mathrm{c}}\end{array}$

$\pm 0.19 \quad \pm 0.45 \quad \pm 0.03 \quad \pm 0.07$

PrxQ

WT WT NDB1 NDB1

$\begin{array}{llll}\mathrm{NO}_{3}{ }^{-} & \mathrm{NH}_{4}^{+} & \mathrm{NO}_{3}{ }^{-} & \mathrm{NH}_{4}^{+}\end{array}$

Figure 8. Expression of redox sensors and transmitters in NDB1-suppressing and WT plants grown on $\mathrm{NH}_{4}{ }^{+}$and $\mathrm{NO}_{3}{ }^{-}$(control) as the only source of nitrogen. Transcript levels for (A) chloroplast glutathione peroxidase-like (GPX) GPX1 and GPX7; (B) cytosolic GPX2; (C) mitochondrial GPX6; (D) chloroplast glutaredoxin (Grx) GrxS14; (E) mitochondrial PrxIIF; (F) chloroplast NADPH-dependent thioredoxin reductase $\mathrm{C}$ (NTRC) and thioredoxins (TRX) TRXx and TRXy2; (G) cytosolic peroxiredoxin (Prx) PrxIIc and chloroplast 2Cys PrxA; and (H) PrxQ protein levels. Bars or bands with different letters are statistically different $(p<0.05)$ by ANOVA. 


\section{Discussion}

\subsection{NDB1-Suppressed Line Does Not Show a Growth Phenotype or Over-Reduction under} Ammonium Nutrition

NDB1 knock-down plants do not show a growth phenotype, but have similar growth to WT plants in either $\mathrm{NO}_{3}{ }^{-}$or $\mathrm{NH}_{4}{ }^{+}$-supplied hydroponic growth conditions (Figure 1A,B). Previously, it has been shown that the NDB1 suppressor line 1.5 (used in this study) grown on soil exhibited decreased biomass [16]. These inconsistent phenotypic responses can be attributed to different growth conditions, e.g., nutrient availability, daylight period ( $10 \mathrm{~h}$ versus $8 \mathrm{~h}$ in the present study), or light intensity (80 versus $150 \mu \mathrm{mol} \mathrm{m} \mathrm{m}^{-2} \mathrm{~s}^{-1}$ ).

Under nitrate conditions, the $\mathrm{NADP}(\mathrm{H})$ pool showed a reduced trend in the NDB1 suppressor line (Figure 2). Since ammonium nutrition greatly increases cell redox state [42], plants with impaired NDB1 were expected to show cellular over-reduction. Surprisingly, under ammonium nutrition, NDB1 knock-down plants exhibited a similar increase in redox state as WT plants (Figure 2). Maintenance of redox homeostasis is central to plant survival, especially under conditions where elevated redox input from the cytosol to the mtETC is expected. We have previously shown that growth of $A$. thaliana under long-term $\mathrm{NH}_{4}{ }^{+}$supply results in up-regulation of NDB1 expression, among all additional dehydrogenases [42]. Therefore, to compensate for NDB1 suppression, induction of other type II dehydrogenases might be suspected. However, a lower total leaf respiratory rate in NDB1 knock-down plants under ammonium nutrition compared with WT (Table 1) strongly suggests that NDB1 knock-down plants do not fully compensate for the deficiency in NADPH-dependent NDex under these conditions. Noteworthy, the differences in total respiration between genotypes grown on $\mathrm{NH}_{4}{ }^{+}$did not result from lower activity of terminal oxidases, since both $\mathrm{V}_{\text {cyt }}$ and $\mathrm{V}_{\text {alt }}$ were comparable between WT and NDB1 knock-down plants (Table 1).

\subsection{Ammonium Nutrition Causes Less Oxidative Injury in NDB1 Knock-Down Plants}

Previously, we have shown that long-term ammonium nutrition results in reductive stress leading to increased ROS production, and consequently resulting in oxidative injury to biomolecules [42]. NDB1 activity seems to be especially important for plant growth under stress conditions, including ammonium nutrition [42], but the opposite was observed, in that the analyzed NDB1 suppressor plants appeared to be more resistant to $\mathrm{NH}_{4}{ }^{+}$treatment. This observation is supported by data on the second examined transgenic line (8.7), similarly, suppressed for NDB1 [16], which we present in Supplementary Materials Figures S2-S7. All measured stress parameters, including lipid peroxidation, protein carbonylation, and the expression of the stress marker UPOX (Figure 4), indicated milder oxidative stress in tissues of NDB1 knock-downs than in WT plants grown on $\mathrm{NH}_{4}{ }^{+}$. This may be the consequence of lower ROS generation, higher capacity of antioxidant systems, or both in the NDB1 knock-down plants during $\mathrm{NH}_{4}{ }^{+}$nutrition as compared with WT plants.

In contrast to what was observed in WT plants [42] under ammonium nutrition, $\mathrm{H}_{2} \mathrm{O}_{2}$ content in the A. thaliana NDB1 knock-down line was unchanged (Figure 3A). A defect in the mtETC often correlates with alterations in ROS metabolism, mainly concerning complex I mutants [51-54]. In contrast to complex I dysfunction, genetic modifications of the alternative pathways result in substantially milder phenotypic expression, being mainly affected during stress conditions, as seen in AOX suppressor plants [55-57]. Furthermore, in Nicotiana sylvestris NDB1-suppressor and A. thaliana NDB4 knock-down plants, no elevated ROS levels were observed [58,59]. Since long-term ammonium nutrition primarily induces mitochondrial ROS production [42,43], the lower ROS content in $\mathrm{NH}_{4}{ }^{+}$-treated NDB1 knock-down plants could be attributable to lower ROS generation in this compartment. Indeed, lower ROS localization was detected in mitochondria during ammonium nutrition of NDB1 knock-down plants compared with WT (Figure 3B). Under optimal growth conditions, the rate of mitochondrial ROS production is approximately 20 times lower than in chloroplasts [60], but may be more substantial under stress conditions that create a mitochondrial ROS 
burst and lead to oxidative damage in tissues [61]. An interesting observation is that dysfunction in one alternative dehydrogenase (mtETC component), whose activity is considered a mechanism that greatly reduces ROS production, does not lead to higher mtROS content under specific stress conditions.

\subsection{Improved Resistance of the NDB1 Knock-Down Line to Ammonium Stress Is Not Related to Ascorbate-Dependent Antioxidant Systems but May Be Attributable to a Glutathione-Dependent System}

To determine why the NDB1 suppressor line shows less oxidative injury under ammonium nutrition, we analyzed changes in antioxidant system functioning between both genotypes under stress conditions. Foyer-Halliwell-Asada cycle function did not appear to be significantly affected by NDB1 dysfunction, since MDHAR and DHAR activities (Figure 5C), and APX protein level (Figure 5B) were similar in WT and NDB1 knock-down plants. Furthermore, we did not observe any significant differences in the activity of SOD isoenzymes (Supplementary Materials Figure S1).

We observed that, under nitrate nutrition, the ascorbate redox state in NDB1 knock-down plants was even further reduced compared with WT plants (Figure 5A). Redox-related metabolic changes in transgenic N. sylvestris NDB1 sense-suppression plants have previously been shown to correspond with altered ascorbate content [62]. In a metabolomics study, a negative correlation between NADPH level and DHA content was observed [62], which is in line with the decreased DHA levels observed in NDB1 A. thaliana knock-down plants in the present study (Figure 5A). Changes in ascorbate redox state may be the result of increased availability of substrate (NADPH) for MDHAR. It was proposed in [62] that changes in ascorbate level may be connected downstream to the NDB1 defect, because ascorbate synthesis takes place in the mtETC. However, it is possible that the changes in ascorbate content/reduction state may instead reflect the chloroplastic pool, since this is the main ascorbate reservoir induced under stress conditions [63]. Although no changes in Foyer-Halliwell-Asada cycle function were detected in tissue extracts between analyzed genotypes (Figure 5B,C), local changes in the activity of enzymes, affecting low-mass antioxidant reduction status in organelles, cannot be excluded.

Clearly, NDB1 knock-down A. thaliana had a marked elevated total glutathione content (Figure 6A). Comparing the rate of oxidation of different ROS forms by ascorbate and glutathione, it appears that glutathione might represent the more potent antioxidant [30] and therefore plays a key role in plant stress tolerance. This effect may be of significant importance since, in Arabidopsis cells, the highest glutathione content was found in mitochondria [64], and thus GSH is presumably the primary mitochondrial ROS scavenger. In conclusion, the high glutathione levels in tissues of NDB1 knock-down plants could primarily be responsible for efficient ROS detoxification in mitochondria (Figure 3B), which was shown to be the predominant ROS source during $\mathrm{NH}_{4}{ }^{+}$nutrition.

Elevated total glutathione content may be achieved by the induction of glutathione-synthesizing enzymes located in chloroplasts [65]. Accordingly, $\mathrm{NH}_{4}{ }^{+}$grown NDB1 knock-down plants showed an up-regulation of GSH1 and GSH2 (Figure 6B). However, glutathione antioxidant potential depends not only on absolute glutathione concentration, but also on its redox state. The glutathione pool of NDB1 knock-down plants showed a more reduced redox state than that in WT plants when nourished on $\mathrm{NH}_{4}{ }^{+}$(Figure 6A). A high level of glutathione reduction is primarily triggered by the activity of GR, the main regulatory enzyme [66]. Despite a lack of change in GR protein level (Figure 6C), the $\mathrm{NH}_{4}{ }^{+}$-grown NDB1 knock-down line showed an induction of cytosolic GR1 on the transcript level (Figure 6D). GR1 has been proposed as the major isoform of GR in plants responsive to stress factors [67] and therefore may be responsible for the reduction state of glutathione in $\mathrm{NH}_{4}{ }^{+}$-grown NDB1 knock-down plants.

The glutathione pool is also implicated in the direct protection of proteins against irreversible oxidative injury due to the $S$-glutathionylation process. Cysteine (Cys) residues in proteins are exposed to modification by ROS in a three-step reaction to successively form sulphenic acid $(\mathrm{Cys}-\mathrm{SOH})$, sulphinic acid $\left(\mathrm{Cys}-\mathrm{SO}_{2} \mathrm{H}\right)$, and sulphonic acid $\left(\mathrm{Cys}-\mathrm{SO}_{3} \mathrm{H}\right)$, which may lead to protein inactivation. Advanced oxidation of Cys residues is irreversible and leads to inevitable 
protein degradation, although the $\mathrm{Cys}-\mathrm{SOH}$ group may be protected against further oxidation by reversible $S$-glutathionylation [68]. Glutathionylation typically occurs under oxidative stress conditions and plays an important role in regulation and signaling [69]. Some studies indicate that, under oxidative stress conditions, the activity of enzymes associated with primarily carbon metabolism may be down-regulated due to glutathionylation [69], allowing more effective antioxidant protection of cells. Additionally, reversible S-glutathionylation is part of the catalytic cycle of some glutathione-dependent enzymes, including DHAR [23]. Ammonium nutrition results in increased protein glutathionylation in both genotypes, although a higher level of $S$-glutathionylated proteins was observed in NDB1 knock-down plants (Figure 7). Unfortunately, we cannot determine whether increased $S$-glutathionylation is the result of the protection of Cys-SOH groups in oxidized proteins or whether it is aimed at the regulatory adjustment of metabolism; however, both processes may be responsible for improved tolerance of $\mathrm{NDB1}$ knock-down plants to $\mathrm{NH}_{4}{ }^{+}$. The regeneration of native Cys residues in proteins depends on GSH but requires GRXs activity. Interestingly, ammonium treatment results in the specific down-regulation of expression of several members of the GRX gene family [70]. In the present study, we measured only the transcript level of GrxS14, confirming the influence of $\mathrm{NH}_{4}{ }^{+}$on Grx expression (Figure 8D). Moreover, we observed that in NDB1 knock-down plants under nitrate conditions, the transcript level of GrxS14 was lower than in WT plants but was not regulated by $\mathrm{NH}_{4}{ }^{+}$(Figure 8D). This observation may suggest that, under ammonium nutrition, Cys residues in NDB1 knock-downs grown on $\mathrm{NH}_{4}{ }^{+}$are more efficiently regenerated to their native forms, meaning that NDB1-suppressor lines have more efficient protection against oxidative damage of proteins. However, a reduced GrxS14 transcript level in NDB1 knock-down plants may indicate that the down-regulation of GRX expression is not specifically in response to $\mathrm{NH}_{4}{ }^{+}$nutrition, as was suggested previously [70], but rather to changes in the tissue redox state. The influence of NDB1 suppression on the expression of other GRX genes and on GRX activity therefore requires further research.

\subsection{NDB1 Deletion Leads to Changes in the Expression of Genes Involved in the Redox Regulatory Network}

Following the observation of different effects of ammonium nutrition on the level of GRX transcripts in WT and NDB1 knock-down plants (Figure 8D), we analyzed the expression of other genes engaged in redox signal integration. Redox-sensitive proteins were classified into two classes: redox sensors, including Prx and GPX, and redox transmitters, containing a large family of Grxs and TRXs [71]. In general, we can conclude that the expression of all redox-sensitive genes evaluated was regulated differently by $\mathrm{NH}_{4}{ }^{+}$in WT and in NDB1 knock-down plants (Figure 8A,B,D-F), with the exception of GPX2 and GPX8 isoforms, whose expression was unchanged irrespective of growth conditions and genotype (Figure 8B, Supplementary Materials Figure S7C).

Among the four Prx, which are targeted to the plastids, we estimated the expression of 2Cys PrxA and PrxQ (Figure 8G,H). 2Cys PrxA was strongly down-regulated by $\mathrm{NH}_{4}{ }^{+}$in WT plants but not in NDB1 knock-down plants. In contrast, in both genotypes, the protein level of PrxQ was increased in response to $\mathrm{NH}_{4}{ }^{+}$, but a greater increase was observed in the NDB1-suppressing line. Those observations suggest that both Prx can have markedly different roles in leaf cell metabolism, especially under stress conditions. In plants, the highly abundant 2Cys Prx is involved in protecting photosynthetic ETC functioning as reduced amounts of 2Cys Prx were shown to result in decreased levels of D1 protein and of the light-harvesting protein complex associated with photosystem II [72]. 2Cys Prx activity is related to the functioning of intermembrane protein complexes, which enforces that 2Cys $\operatorname{Prx}$ (at least in the majority of its conformational states) is associated with thylakoid membranes [73]. By contrast, PrxQ of Arabidopsis was shown to be a soluble protein in the lumen of the thylakoid membranes [74]. All Prx are thiol peroxidases and might function in oxidant detoxification [71]. However, according to available data, 2Cys Prx, in addition to a role in photosynthetic energy dissipation [73], and depending on conformational state, may also function as chaperones [75]. The precise function of the 2Cys Prx chaperone activity is not yet known, but it has been suggested that its binding to stromal fructose-1,6-bisphosphatase allows Calvin 
cycle activity to be maintained under conditions of excessive ROS production [76]. In addition to substrate specificity, both evaluated Prx may differ; 2Cys Prx catalyzes the detoxification of $\mathrm{H}_{2} \mathrm{O}_{2}$, alkyl hydroperoxides, and reactive nitrogen peroxides [77], while PrxQ has been demonstrated as an $\mathrm{H}_{2} \mathrm{O}_{2}$ peroxidase with very low activity toward lipid peroxides [78]. In the context of our results, high light conditions (resulting in higher production of NADPH) have been shown to lead to decreased 2Cys PrxA transcription but increased PrxQ [79]. Furthermore, PrxQ but not 2Cys PrxA was highly induced by the addition of oxidant to Arabidopsis tissues [79]. Finally, the expression of PrxQ was shown to be greatly increased in the hypersensitive response to pathogen treatment [80]. On the basis of these observations alongside our results, we may conclude that 2Cys PrxA is down-regulated in response to changes in chloroplastic NADPH and PrxQ is up-regulated in response to $\mathrm{H}_{2} \mathrm{O}_{2}$ and may be an effective organelle-localized antioxidant under stress conditions. However, both Prx are involved in redox sensing and signaling [71].

Interestingly, similarly to PrxQ, the expression of type II Prx was also increased in response to infection by Melampsora larici-populina [80] and both Prx were induced by (pro-) oxidants in the same manner [79]. Also, in our study, changes in cytosolic PrxIIC expression were similar to changes in PrxQ (Figure 8G,H). Therefore, we suggest that PrxIIC also protects NDB1 knock-down plants against oxidative stress under ammonium nutrition.

The regeneration of oxidized Prx requires a supply of electrons from redox transmitters, but target selectivity between chloroplast redox-sensitive proteins exists in this process; NTRC is responsible mainly for 2Cys Prx reduction and PrxQ is regenerated mainly by the proteins of the TRX family [81]. The expression of NTRC and 2Cys Prx has been shown to be strictly co-regulated to maintain proper functioning of the photosynthetic apparatus and the entire chloroplast metabolism [82]. Our results confirm this observation, since the expression of NTRC and 2Cys PrxA is similarly regulated in both genotypes (Figure 8F,G). However, the changes in expression observed in TRXx and TRXy2 do not reflect the altered expression of PrxQ (Figure 8F,G). Furthermore, it should be noted that the Trx-PrxQ system does not show the same specificity as the NTRC-2Cys PrxA system does. 2Cys Prx may also be regenerated by TRX [71]; therefore, the decrease in TRX expression observed in WT plants under ammonium nutrition and in NDB1 knock-down plants may reflect the down-regulation of a subclass of 2Cys Prx (Figure 8F-H).

PrxIIF is recognized as an important component of the mitochondrial defense system against peroxide stress, and is regenerated in a GSH-dependent manner. The specific substrate for PrxIIF is $\mathrm{H}_{2} \mathrm{O}_{2}$, and the reduction of lipid peroxides is catalyzed through this enzyme approximately 10 times less efficiently [83]. Studies on the response of PrxIIF to stress conditions have classified PrxIIF as non-responsive to high light and salt stress $[79,84]$, but it's up-regulation has been shown as a result of cadmium treatment [83]. Ammonium stress differentially affects PrxIIF expression in WT and NDB1 knock-down plants (Figure 8E). Lower PrxIIF abundance might have diminished the antioxidant protection of mitochondria of WT plants grown on $\mathrm{NH}_{4}{ }^{+}$, leading to higher $\mathrm{H}_{2} \mathrm{O}_{2}$ content in those organelles (Figure 3B). Indeed, it was shown previously that under optimal growth conditions, defects in PrxIIF may be compensated for by other compounds of the antioxidant defense system. However, such compensation is insufficient under stress conditions [83], which suggests an essential role for PrxIIF in organellar redox homeostasis.

Plant GPXs catalyze the reduction of $\mathrm{H}_{2} \mathrm{O}_{2}$ as well as different kinds of lipid peroxides by using TRX as an electron donor. The observed changes in GPX1 and GPX7 expression are relatively small (Figure 8A), with the mitochondrial isoform of GPX showing the only stress-responsive change (Figure 8C). Altogether, among redox sensors, which inactivate ROS, mostly GPX (cytosolic GPX1 and GPX7, and mitochondrial GPX6) and Prx (PrxIIF, PrxIIC, and PrxQ), are up-regulated in NDB1 knock-down plants under ammonium nutrition. We hypothesize that this up-regulation increases the efficiency of ROS detoxification (including organic peroxide detoxification detected as lower levels of lipid peroxidation, Figure 4A) while enabling plants to better adjust their metabolism to stress conditions (Figure 9). 


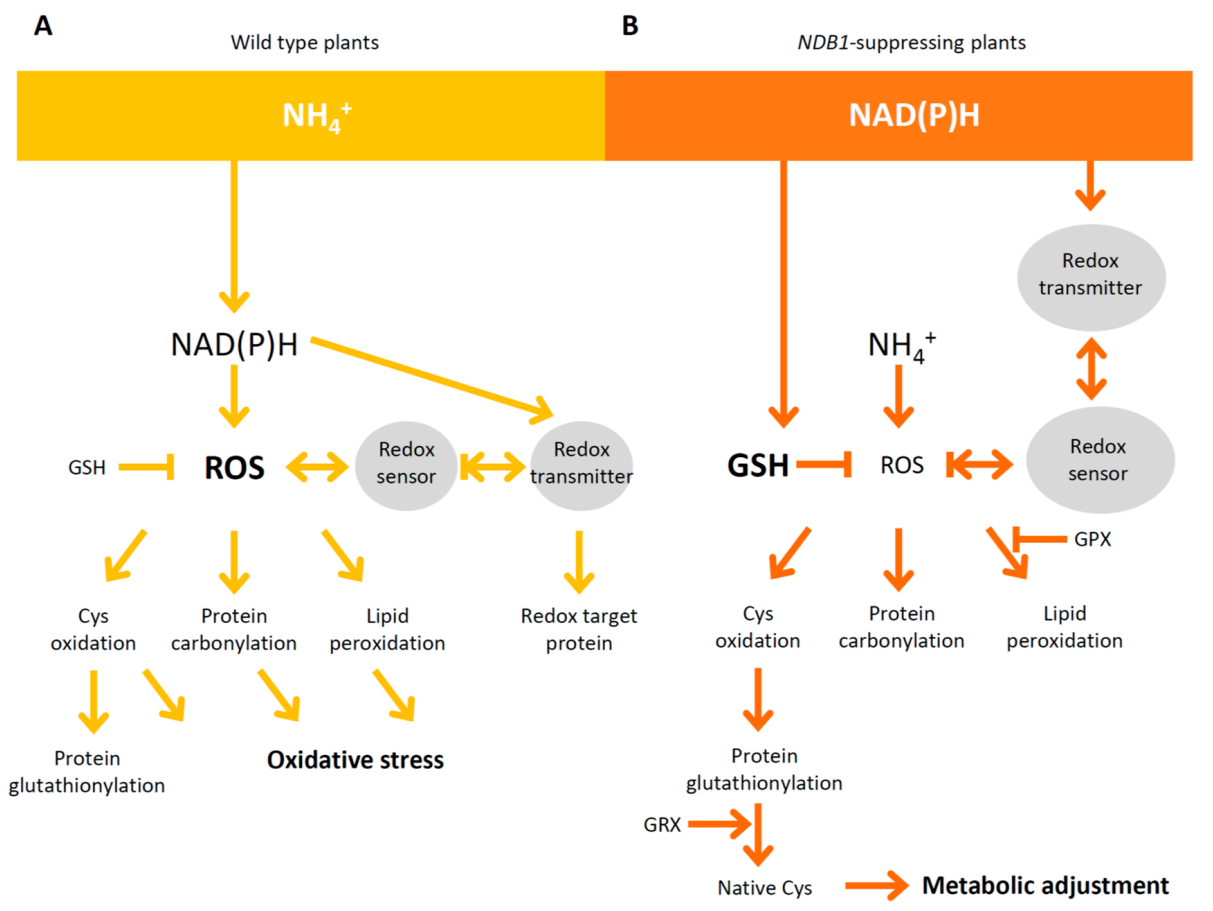

Figure 9. Schematic comparison between redox-related changes occurring in WT and NDB1 suppressor plants grown on ammonium as the sole nitrogen source. (A) Changes in redox homeostasis in WT plants are a direct consequence of ammonium assimilation, and a secondary effect is the induction of redox transmitters/sensors and ROS accumulation leading to protein carbonylation, lipid peroxidation, and oxidation of Cys residues, which causes oxidative stress in $\mathrm{NH}_{4}{ }^{+}$-grown WT plants; (B) NDB1 knock-down plants have an initial higher redox potential, and can rapidly induce changes in redox-related sensors/transmitters and glutathione content; in these plants, $\mathrm{NH}_{4}{ }^{+}$nutrition is an additional factor that does not affect ROS content in tissues. Instead of exhibiting symptoms of oxidative stress symptoms, NDB1 knock-down plants undergo metabolic adjustment to a high redox input during $\mathrm{NH}_{4}{ }^{+}$nutrition. Sharp arrows indicate stimulatory influences, whereas blunt arrows represent inhibitory effects.

\section{Material and Methods}

\subsection{Plant Material and Growth Conditions}

Arabidopsis thaliana plants of ecotype Columbia-0 (WT) and their derivatives, NDB1-suppressed by RNA interference line 1.5 (named NDB1) and 8.7 (NDB1 8.7, Supplementary Materials Figure S2) [16], were grown hydroponically using an Araponics SA system (Liège, Belgium). Seeds were sown in half-strength [85] basal salt mixture with $1 \%$ agar, and after germination (1 week), deionized water in the hydroponic box was replaced with the nutrient solution described in [42], which was constantly aerated and replaced twice a week thereafter. The constant sole source of nitrogen for the plants was $5 \mathrm{mM} \mathrm{NO}_{3}{ }^{-}$or $5 \mathrm{mM} \mathrm{NH}_{4}{ }^{+}$. $\mathrm{NO}_{3}{ }^{-}$-nourished plants were used as controls. Plants were grown for 8 weeks in a growth chamber under an 8 -h photoperiod at $150 \mu \mathrm{mol} \mathrm{m}^{-2} \mathrm{~s}^{-1}$ photosynthetically active radiation (PAR, daylight and warm white, 1:1; LF-40W, Phillips, Pila, Poland), day/night temperature of $21^{\circ} \mathrm{C} / 18{ }^{\circ} \mathrm{C}$, and approximately $70 \%$ relative humidity. All assays were carried out on leaf samples collected in the middle of the light period.

\subsection{Phenotype Analysis}

Ten to 25 plants were randomly selected from two plant cultures (grown on $\mathrm{NO}_{3}{ }^{-}$or $\mathrm{NH}_{4}{ }^{+}$, respectively) and weighed for fresh weight determination (FW). Representative rosettes were photographed. 


\subsection{Respiratory Measurements}

Leaves were weighed and pre-incubated before respiratory measurement in an assay solution containing $30 \mathrm{mM}$ 2-(N-morpholino)ethanesulfonic acid (MES), pH 6.2 supplemented with $0.2 \mathrm{mM}$ $\mathrm{CaCl}_{2}$. Oxygen consumption rates were measured in $3.0 \mathrm{~mL}$ assay solution using a Clark-type oxygen electrode (Rank Brothers Ltd., Cambridge, UK) in the dark at a constant temperature of $25^{\circ} \mathrm{C}$ [86]. For inhibitor treatments, $10 \mathrm{mM} \mathrm{KCN}$ or $20 \mathrm{mM}$ salicylhydroxamic acid (SHAM) in DMSO were used. To measure residual respiration, both inhibitors were added. Total respiration $\left(V_{t}\right)$, alternative pathway capacity $\left(\mathrm{V}_{\text {alt }}\right)$, and cytochrome pathway capacity $\left(\mathrm{V}_{\text {cyt }}\right)$ values were determined after the subtraction of the value for residual respiration.

\subsection{Quantitative RT-PCR Analyses}

Total RNA was extracted from $100 \mathrm{mg}$ of leaf tissue using a Syngen Plant RNA Mini kit (Syngen Biotech, Wrocław, Poland). DNase digestion was performed using an RNase-free DNase Set (Qiagen, Hilden, Germany). Complementary DNA was synthesized from $1 \mu \mathrm{g}$ of total RNA as a template using reverse transcriptase and oligo-dT primers from a Revert Aid $\mathrm{H}$ minus first-strand cDNA synthesis kit, according to the manufacturer's protocol (Thermo Fisher Scientific Inc., Waltham, MA, USA). Thereafter, RNA digestion was performed as described in [87]. Relative transcript abundance was quantified by comparative quantitation analysis. Transcript content was analyzed using iTaq Universal SYBR Green Supermix (Bio-Rad, Hercules, CA, USA) according to the manufacturer's instructions.

Primer pairs for GPX1 (At2g25080), GPX6 (At4g11600), and GR1 (At3g24170), were as described in [42], and for UPOX (At2g21640; [50]), as described previously in [88]. New primers were designed for GrxS14 (At3g54900), 2Cys PrxA (At3g11630), PrxIIC (At1g65970), PrxIIF (At3g06050), TRXx (At1g50320), TRXy2 (At1g43560), NTRC (At2g41680), GR2 (At3g54660), GSH1 (At4g23100), GSH2 (At5g27380), GPX2 (At2g31570), GPX7 (At4g31870) and GPX8 (At1g63460) (Supplementary Materials Table S1), with one sequence covering an exon-exon junction if present in the gene sequence. Quantitative RT-PCR reactions were performed using a thermo cycler (CFX Connect ${ }^{\mathrm{TM}}$, Bio-Rad) with an annealing temperature of $60{ }^{\circ} \mathrm{C}$. Transcript abundance was normalized to the expression of the reference $P P 2 A$ (At1g13320) gene [89]. Transcript content and qRT-PCR efficiency of target genes were quantified as described in [90]. Results were expressed in relation to those in $\mathrm{NO}_{3}{ }^{-}$-grown plants (value of 1).

\subsection{Analysis of Metabolites}

A previously reported method was used for the extraction and analysis of NAD $(\mathrm{P})(\mathrm{H})[91]$. Hydrogen peroxide content was determined according to [92] and quantified with reference to an internal standard $\left(5 \mathrm{nmol} \mathrm{H}_{2} \mathrm{O}_{2}\right.$ ). Ascorbate was extracted from leaf tissue using $0.1 \mathrm{M}$ hydrochloric acid, and the levels of the reduced (AsA) and oxidized (DHA) forms of ascorbate were assayed according to the [93] method. Glutathione extraction was performed in 5\% meta phosphoric acid and GSH was quantified using the enzymatic assay of [94]. Lipid peroxidation was estimated by measuring the secondary oxidation product MDA as described in [95]. Oxidized proteins were labeled with 2,4-dinitrophenylhydrazine (DNPH) and quantified by measuring carbonylated protein derivatives in tissue extracts according to [96]. Soluble protein content in the samples was estimated by the [97] method using bovine serum albumin (BSA) as the standard.

\subsection{Confocal Fluorescent Imaging of Intracellular ROS}

In vivo ROS localization was determined by detecting the fluorescence of DCF and colocalization with mitochondria and chloroplasts using confocal laser scanning microscopy according to the method described in [98], with minor modifications. The upper epidermis was removed from fresh plant leaves, and tissues were cut into small sections (approx. $5 \mathrm{~mm}$ ). Samples were double-stained with cell-permeant 100 nM MitoTracker Orange (reduced CM- $\mathrm{H}_{2}$ TMRos, Molecular Probes, Thermo 
Fisher Scientific, Waltham, MA, USA) and $20 \mu \mathrm{M} 2^{\prime}, 7^{\prime}$-dichlorodihydrofluorescein diacetate (DCF-DA, Molecular Probes, Thermo Fisher Scientific) under dark incubation for $15 \mathrm{~min}$ at room temperature (RT). The leaf pieces were washed in water three times for $5 \mathrm{~min}$ and then placed on a glass coverslip. MitoTracker Orange fluorescence was induced with a $561 \mathrm{~nm}$ helium-neon laser at emission of 570-620 nm. DCF-fluorescence was measured using the $488 \mathrm{~nm}$ line of an argon laser and was monitored at 500-550 nm. Chlorophyll fluorescence was induced with a $633 \mathrm{~nm}$ helium-neon laser and detected at $663-738 \mathrm{~nm}$. Images were acquired using a NIKON A1R MP confocal laser scanning system (LSM-510, Carl Zeiss, Oberkochen, Germany) at 60× (numerical aperture 1.2) water immersion objective. Negative control images were obtained by omitting fluorescent probes to remove all signal from tissues except for chlorophyll autofluorescence. For individual cells, Pearson's colocalization coefficient was calculated between the green/red and green/far red channels using the Nis-Elements 3.22 imaging software (Nikon Co., Tokyo, Japan).

\subsection{Western Blotting Analyses}

To determine protein levels, tissue was homogenized with 2.5 volumes of extraction buffer and $5 \mu \mathrm{L}$ of the resulting extract was used for GR, $15 \mu \mathrm{L}$ for APX, $10 \mu \mathrm{L}$ for PrxQ, and $3 \mu \mathrm{L}$ for MnSOD. Extracts were subjected to sodium dodecyl sulfate-polyacrylamide gel electrophoresis (SDS-PAGE). The polypeptides were electroblotted onto nitrocellulose membranes using wet transfer (Bio-Rad, Hercules, CA, USA) and probed with anti-PrxQ (diluted 1:5000; Agrisera, Vännäs, Sweden), anti-APX (diluted 1:2000; Agrisera), anti-GR (diluted 1:4000; Agrisera), or anti-MnSOD (diluted 1:1000; Sigma-Aldrich, St. Louis, MO, USA) primary antibodies overnight at $4{ }^{\circ} \mathrm{C}$, followed by anti-rabbit secondary antibodies conjugated to horseradish peroxidase (diluted 1:10,000 for APX and MnSOD, 1:40,000 for GR, and 1:20,000 for PrxQ determination; Bio-Rad). The quantification of protein $S$-glutathionylation was achieved after the detection of glutathione-protein complexes. Tissue extracts $(20 \mu \mathrm{L})$ were mixed with Laemmli sample buffer containing $N$-ethylmaleimide (NEM, final concentration $5 \mathrm{mM})$; NEM $(2.5 \mathrm{mM})$ was also present in the blocking buffer to prevent reduction of GSH adducts by thiol-containing proteins [99]. For immunoblotting, anti-GSH (diluted 1:1000; Abcam, Cambridge, UK) antibodies were used, with anti-mouse antibodies (diluted 1:20,000, Bio-Rad) as secondary antibodies. For the determination of carbonylated proteins in electrophoretically separated protein extracts $(5 \mu \mathrm{L})$, an OxyBlot detection kit (Millipore, Billerica, MA, USA) was used according to the manufacturer's protocol. Visualization was performed using a chemiluminescence kit (Clarity ${ }^{\mathrm{TM}}$ Western ECL, Bio-Rad), and signals were detected using a Chemi-Doc imaging system (Bio-Rad). Specific bands were referred to pre-stained protein markers (Bio-Rad). The densitometry of bands for analyzed proteins or of the whole blot lane for carbonylated and glutathionylated proteins was quantified using Image-Lab 5.2 software (Bio-Rad) after background correction.

\subsection{Enzyme Activity Assay}

For the measurement of ascorbate-glutathione cycle enzymes activity, leaves were homogenized in $50 \mathrm{mM}$ phosphate buffer, $\mathrm{pH} 7.0,1 \mathrm{M} \mathrm{NaCl}, 1 \%(w / v)$ PVP, and $1 \mathrm{mM}$ EDTA (as described in [100]). DHAR was determined according to the method of [101]. MDHAR and GR were assayed as in [102]. Superoxide dismutase (SOD) isoforms were visualized in gel by the method of [103] after electrophoretic separation of protein extracts $(6 \mu \mathrm{L})$ on $12 \%$ polyacrylamide gels.

\subsection{Statistical Analysis}

Results are expressed as the mean value \pm standard deviation (SD) of $n$ measurements $(n=3-25)$ taken from at least two independent plant cultures. To analyze the statistical significance of observed differences, a one-way analysis of variance (ANOVA) with Tukey's post-hoc test at $p$-values $\leq 0.05$ was performed using Statistica 13.1 software (StatSoft, Inc., Tulsa, OK, USA). 


\section{Conclusions}

We have shown that the impairment of NDB1 in mitochondrial ETC does not trigger major oxidative stress in plants challenged with $\mathrm{NH}_{4}{ }^{+}$treatment. Moreover, high light conditions were not a burden for plants with suppressed NDB1 [16,62]. On the basis of a microarray study to identify a response overlap, the NDB1 Arabidopsis thaliana suppressor line exhibited a similar profile to OsHsfA21 plants, which have been characterized by improved tolerance to stress, including pathogen resistance [16]. It has also been shown that the suppression of another NADH-dependent NDex isoform, NDB4, improved salinity stress tolerance [59]. Altogether, these findings may lead to the assumption that the suppression of NDex and subsequent changes in redox metabolism induce cross tolerance among plants to withstand other stresses. This effect may be attributed to the observation that various stresses produce a similar effect to oxidative stress at the cellular level. An epigenetic response in plants may transmit the acquired stress resistance to their progeny $[104,105]$. This study shows that improved sensitivity to changes connected with altered redox/ROS status in NDB1 knock-down plants may be beneficial during stress related to ammonium nutrition.

Supplementary Materials: Supplementary materials can be found at http:/ /www.mdpi.com/1422-0067/19/5/ 1412/s1.

Author Contributions: A.P., B.S., and M.O.-B. conceived and designed the experiments; M.O.-B. performed respiratory measurements; A.P., K.B., M.J., and M.O.-B. carried out RT-PCR analysis; A.P., A.T., B.S., M.J., and M.O.-B. measured metabolites and enzyme activities; A.P. performed CLSM microscopy; A.T., K.B., M.B., M.J., and M.O.-B. performed immunoblotting; A.P., B.S., K.B., and M.O.-B. wrote the paper; and A.G.R revised the manuscript.

Acknowledgments: This work was partially supported by grant 2011/01/N/NZ3/02953 from the National Science Centre (NCN, Poland) given to A.P. A.P. and M.O.-B. were the beneficiaries of a scholarship from the Polish Minister of Science and Higher Education. The authors thank Bohdan Paterczyk from the Faculty of Biology (University of Warsaw) for support during CLSM analysis. We are grateful to Anna Książek from the Faculty of Biology (University of Warsaw) for assistance with RT-PCR studies.

Conflicts of Interest: The authors declare no conflict of interest. The funding sponsors had no role in the design of the study; in the collection, analyses, or interpretation of data; in the writing of the manuscript; and in the decision to publish the results.

\section{Abbreviations}

$\begin{array}{ll}\text { APX } & \text { ascorbate peroxidase } \\ \text { AsA } & \text { reduced form of ascorbate } \\ \text { DHA } & \text { oxidized form of ascorbate (dehydroascorbate) } \\ \text { DHAR } & \text { dehydroascorbate reductase } \\ \text { GPX } & \text { glutathione peroxidase-like } \\ \text { GR } & \text { glutathione reductase } \\ \text { GRX } & \text { glutaredoxin } \\ \text { GSH } & \text { reduced form of glutathione } \\ \text { GSSG } & \text { oxidized form of glutathione (glutathione disulfide) } \\ \text { MDHAR } & \text { monodehydroascorbate reductase } \\ \text { NDB1 } & \text { external NADPH dehydrogenase } \\ \text { NTRC } & \text { NAPDH-dependent thioredoxin reductase C } \\ \text { Prx } & \text { peroxiredoxin } \\ \text { ROS } & \text { reactive oxygen species } \\ \text { SOD } & \text { superoxide dismutase } \\ \text { TRX } & \text { thioredoxin } \\ \text { UPOX } & \text { protein up-regulated by oxidative stress }\end{array}$




\section{References}

1. Noctor, G. Metabolic signalling in defence and stress: The central roles of soluble redox couples. Plant Cell Environ. 2006, 29, 409-425. [CrossRef] [PubMed]

2. Suzuki, N.; Miller, G.; Morales, J.; Shulaev, V.; Torres, M.A.; Mittler, R. Respiratory burst oxidases: The engines of ROS signaling. Curr. Opin. Plant Biol. 2011, 14, 691-699. [CrossRef] [PubMed]

3. Gakière, B.; Fernie, A.R.; Pétriacq, P. More to NAD+ than meets the eye: A regulator of metabolic pools and gene expression in Arabidopsis. Free Radic. Biol. Med. 2018. [CrossRef] [PubMed]

4. Noctor, G.; De Paepe, R.; Foyer, C.H. Mitochondrial redox biology and homeostasis in plants. Trends Plant Sci. 2007, 12, 125-134. [CrossRef] [PubMed]

5. Møller, I.M. Plant mitochondria and oxidative stress: Electron transport, NADPH turnover, and metabolism of reactive oxygen species. Annu. Rev. Plant Biol. 2001, 52, 561-591. [CrossRef] [PubMed]

6. Rasmusson, A.G.; Geisler, D.A.; Møller, I.M. The multiplicity of dehydrogenases in the electron transport chain of plant mitochondria. Mitochondrion 2008, 8, 47-60. [CrossRef] [PubMed]

7. Michalecka, A.M.; Agius, S.C.; Møller, I.M.; Rasmusson, A.G. Identification of a mitochondrial external NADPH dehydrogenase by overexpression in transgenic Nicotiana sylvestris. Plant J. 2004, 37, 415-425. [CrossRef] [PubMed]

8. Elhafez, D.; Murcha, M.W.; Clifton, R.; Soole, K.L.; Day, D.A.; Whelan, J. Characterization of mitochondrial alternative $\mathrm{NAD}(\mathrm{P}) \mathrm{H}$ dehydrogenases in Arabidopsis: Intraorganelle location and expression. Plant Cell Physiol. 2006, 47, 43-54. [CrossRef] [PubMed]

9. Considine, M.J.; Holtzapffel, R.C.; Day, D.A.; Whelan, J.; Millar, A.H. Molecular distinction between alternative oxidase from monocots and dicots. Plant Physiol. 2002, 129, 949-953. [CrossRef] [PubMed]

10. Rasmusson, A.G.; Wallström, S.V. Involvement of mitochondria in the control of plant cell NAD $(\mathrm{P}) \mathrm{H}$ reduction levels. Biochem. Soc. Trans. 2010, 38, 661-666. [CrossRef] [PubMed]

11. Padmasree, K.; Padmavathi, L.; Raghavendra, A.S. Essentiality of mitochondrial oxidative metabolism for photosynthesis: Optimization of carbon assimilation and protection against photoinhibition. Crit. Rev. Biochem. Mol. Biol. 2002, 37, 71-119. [CrossRef] [PubMed]

12. Noguchi, K.; Yoshida, K. Interaction between photosynthesis and respiration in illuminated leaves. Mitochondrion 2007, 8, 87-99. [CrossRef] [PubMed]

13. Møller, I.M.; Rasmusson, A.G.; Fredlund, K.M. NAD(P)H-ubiquinone oxidoreductases in plant mitochondria. J. Bioenerg. Biomemb. 1993, 25, 377-384. [CrossRef]

14. Potters, G.; Horemans, N.; Jansen, M.A. The cellular redox state in plant stress biology-A charging concept. Plant Physiol. Biochem. 2010, 48, 292-300. [CrossRef] [PubMed]

15. Nunes-Nesi, A.; Araújo, W.L.; Fernie, A.R. Targeting mitochondrial metabolism and machinery as a means to enhance photosynthesis. Plant Physiol. 2011, 155, 101-107. [CrossRef] [PubMed]

16. Wallström, S.V.; Florez-Sarasa, I.; Araújo, W.L.; Aidemark, M.; Fernández-Fernández, M.; Fernie, A.R.; Ribas-Carbó, M.; Rasmusson, A.G. Suppression of the external mitochondrial NADPH dehydrogenase, NDB1, in Arabidopsis thaliana affects central metabolism and vegetative growth. Mol. Plant 2014, 7, 356-368. [CrossRef] [PubMed]

17. Suzuki, N.; Koussevitzky, S.; Mittler, R.; Miller, G. ROS and redox signalling in the response of plants to abiotic stress. Plant Cell Environ. 2012, 35, 259-270. [CrossRef] [PubMed]

18. Noctor, G.; Lelarge-Trouverie, C.; Mhamdi, A. The metabolomics of oxidative stress. Phytochemistry 2015, 112, 33-53. [CrossRef] [PubMed]

19. Gill, S.S.; Tuteja, N. Reactive oxygen species and antioxidant machinery in abiotic stress tolerance in crop plants. Plant Physiol. Biochem. 2010, 48, 909-930. [CrossRef] [PubMed]

20. Espinosa-Diez, C.; Miguel, V.; Mennerich, D.; Kietzmann, T.; Sánchez-Pérez, P.; Cadenas, S.; Lamas, S. Antioxidant responses and cellular adjustments to oxidative stress. Redox Biol. 2015, 6, 183-197. [CrossRef] [PubMed]

21. Schertl, P.; Braun, H.P. Respiratory electron transfer pathways in plant mitochondria. Front. Plant Sci. 2014, 5, 163. [CrossRef] [PubMed]

22. Meyer, A.J. The integration of glutathione homeostasis and redox signaling. J. Plant Physiol. 2008, 165, 1390-1403. [CrossRef] [PubMed] 
23. Noctor, G.; Mhamdi, A.; Chaouch, S.; Han, Y.I.; Neukermans, J.; Marquez-Garcia, B.; Foyer, C.H. Glutathione in plants: An integrated overview. Plant Cell Environ. 2012, 35, 454-484. [CrossRef] [PubMed]

24. Deponte, M. Glutathione catalysis and the reaction mechanisms of glutathione-dependent enzymes. Biochim. Biophys. Acta 2013, 1830, 3217-3266. [CrossRef] [PubMed]

25. Dixon, D.P.; Skipsey, M.; Grundy, N.M.; Edwards, R. Stress-induced protein S-glutathionylation in Arabidopsis. Plant Physiol. 2005, 138, 2233-2244. [CrossRef] [PubMed]

26. Foyer, C.H.; Halliwell, B. The presence of glutathione and glutathione reductase in chloroplasts: A proposed role in ascorbic acid metabolism. Planta 1976, 133, 21-25. [CrossRef] [PubMed]

27. Sevilla, F.; Jiménez, A.; Lázaro, J.J. What do the plant mitochondrial antioxidant and redox systems have to say under salinity, drought, and extreme temperature? In Reactive Oxygen Species and Oxidative Damage in Plants under Stress, 1st ed.; Gupta, D.K., Palma, J.M., Corpas, F.J., Eds.; Springer International Publishing: Cham, Switzerland, 2015; pp. 23-55.

28. Geigenberger, P.; Thormählen, I.; Daloso, D.M.; Fernie, A.R. The unprecedented versatility of the plant thioredoxin system. Trends Plant Sci. 2017, 22, 249-262. [CrossRef] [PubMed]

29. Foyer, C.H.; Noctor, G. Ascorbate and glutathione: The heart of the redox hub. Plant Physiol. 2011, 155, 2-18. [CrossRef] [PubMed]

30. Rahantaniaina, M.S.; Tuzet, A.; Mhamdi, A.; Noctor, G. Missing links in understanding redox signaling via thiol/disulfide modulation: How is glutathione oxidized in plants? Front. Plant Sci. 2013, 4, 477. [CrossRef] [PubMed]

31. Zhang, J.; Kirkham, M.B. Antioxidant responses to drought in sunflower and sorghum seedlings. New Phytol. 1996, 132, 361-373. [CrossRef] [PubMed]

32. Garmier, M.; Carroll, A.J.; Delannoy, E.; Vallet, C.; Day, D.A.; Small, I.D.; Millar, A.H. Complex I dysfunction redirects cellular and mitochondrial metabolism in Arabidopsis. Plant Physiol. 2008, 148, 1324-1341. [CrossRef] [PubMed]

33. Vidal, E.A.; Gutierrez, R.A. A systems view of nitrogen nutrient and metabolite responses in Arabidopsis. Curr. Opin. Plant Biol. 2008, 11, 521-529. [CrossRef] [PubMed]

34. Bloom, A.J. Photorespiration and nitrate assimilation: A major intersection between plant carbon and nitrogen. Photosynth. Res. 2015, 123, 117-128. [CrossRef] [PubMed]

35. Zhu, Z.; Gerendás, J.; Bendixen, R.; Schinner, K.; Tabrizi, H.; Sattelmacher, B.; Hansen, U.P. Different Tolerance to Light Stress in $\mathrm{NO}_{3}{ }^{-}$-and $\mathrm{NH}_{4}{ }^{+}$-Grown Phaseolus vulgaris L. Plant Biol. 2000, 2, 558-570. [CrossRef]

36. Guo, S.; Schinner, K.; Sattelmacher, B.; Hansen, U.P. Different apparent $\mathrm{CO}_{2}$ compensation points in nitrate-and ammonium-grown Phaseolus vulgaris and the relationship to non-photorespiratory $\mathrm{CO}_{2}$ evolution. Physiol. Plant. 2005, 123, 288-301. [CrossRef]

37. Noctor, G.; Foyer, C.H. A re-evaluation of the ATP: NADPH budget during C3 photosynthesis: A contribution from nitrate assimilation and its associated respiratory activity? J. Exp. Bot. 1998, 49, 1895-1908. [CrossRef]

38. Escobar, M.A.; Geisler, D.A.; Rasmusson, A.G. Reorganization of the alternative pathways of the Arabidopsis respiratory chain by nitrogen supply: Opposing effects of ammonium and nitrate. Plant J. 2006, 45, 775-788. [CrossRef] [PubMed]

39. Bloom, A.J.; Sukrapanna, S.S.; Warner, R.L. Root respiration associated with ammonium and nitrate absorption and assimilation by barley. Plant Physiol. 1992, 99, 1294-1301. [CrossRef] [PubMed]

40. Gerendás, J.; Zhu, Z.; Bendixen, R.; Ratcliffe, R.G.; Sattelmacher, B. Physiological and biochemical processes related to ammonium toxicity in higher plants. J. Plant Nutr. Soil Sci. 1997, 160, 239-251. [CrossRef]

41. Britto, D.T.; Kronzucker, H.J. Ecological significance and complexity of N-source preference in plants. Ann. Bot. 2013, 112, 957-963. [CrossRef] [PubMed]

42. Podgórska, A.; Gieczewska, K.; Łukawska-Kuźma, K.; Rasmusson, A.G.; Gardeström, P.; Szal, B. Long-term ammonium nutrition of Arabidopsis increases the extrachloroplastic NAD $(\mathrm{P}) \mathrm{H} / \mathrm{NAD}(\mathrm{P})+$ ratio and mitochondrial reactive oxygen species level in leaves but does not impair photosynthetic capacity. Plant Cell Environ. 2013, 36, 2034-2045. [CrossRef] [PubMed]

43. Podgórska, A.; Szal, B. The role of reactive oxygen species under ammonium nutrition. In Reactive Oxygen and Nitrogen Species Signaling and Communication in Plants; Gupta, K., Igamberdiev, A., Eds.; Springer International Publishing: Cham, Switzerland, 2015; Volume 23, pp. 133-153.

44. Britto, D.T.; Kronzucker, H.J. $\mathrm{NH}_{4}{ }^{+}$toxicity in higher plants: A critical review. J. Plant Physiol. 2002, 159, 567-584. [CrossRef] 
45. Bittsánszky, A.; Pilinszky, K.; Gyulai, G.; Komives, T. Overcoming ammonium toxicity. Plant Sci. 2015, 231, 184-190. [CrossRef] [PubMed]

46. Esteban, R.; Ariz, I.; Cruz, C.; Moran, J.F. Review: Mechanisms of ammonium toxicity and the quest for tolerance. Plant Sci. 2016, 248, 92-101. [CrossRef] [PubMed]

47. Taylor, N.L.; Day, D.A.; Millar, A.H. Targets of stress-induced oxidative damage in plant mitochondria and their impact on cell carbon/nitrogen metabolism. J. Exp. Bot. 2004, 55, 1-10. [CrossRef] [PubMed]

48. Szal, B.; Podgórska, A. The role of mitochondria in leaf nitrogen metabolism. Plant Cell Environ. 2012, 35, 1756-1768. [CrossRef] [PubMed]

49. Foyer, C.H.; Noctor, G.; Hodges, M. Respiration and nitrogen assimilation: Targeting mitochondria-associated metabolism as a means to enhance nitrogen use efficiency. J. Exp. Bot. 2011, 62, 1467-1482. [CrossRef] [PubMed]

50. Van Aken, O.; Zhang, B.; Carrie, C.; Uggalla, V.; Paynter, E.; Giraud, E.; Whelan, J. Defining the mitochondrial stress response in Arabidopsis thaliana. Mol. Plant 2009, 2, 1310-1324. [CrossRef] [PubMed]

51. Lee, B.H.; Lee, H.; Xiong, L.; Zhu, J.K. A mitochondrial complex I defect impairs cold-regulated nuclear gene expression. Plant Cell 2002, 14, 1235-1251. [CrossRef] [PubMed]

52. Dutilleul, C.; Garmier, M.; Noctor, G.; Mathieu, C.; Chétrit, P.; Foyer, C.H.; De Paepe, R. Leaf mitochondria modulate whole cell redox homeostasis, set antioxidant capacity, and determine stress resistance though altered signaling and diurnal regulation. Plant Cell 2003, 15, 1212-1226. [CrossRef] [PubMed]

53. Meyer, E.H.; Tomaz, T.; Carroll, A.J.; Estavillo, G.; Delannoy, E.; Tanz, S.K.; Small, I.D.; Pogson, B.J.; Millar, A.H. Remodeled respiration in ndufs 4 with low phosphorylation efficiency suppresses Arabidopsis germination and growth and alters control of metabolism at night. Plant Physiol. 2009, 151, 603-619. [CrossRef] [PubMed]

54. Szal, B.; Łukawska, K.; Zdolińska, I.; Rychter, A.M. Chilling stress and mitochondrial genome rearrangement in the MSC16 cucumber mutant affect the alternative oxidase and antioxidant defense system to a similar extent. Physiol. Plant. 2009, 137, 435-445. [CrossRef] [PubMed]

55. Maxwell, D.P.; Wang, Y.; McIntosh, L. The alternative oxidase lowers mitochondrial reactive oxygen production in plant cells. Proc. Natl. Acad. Sci. USA 1999, 96, 8271-8276. [CrossRef] [PubMed]

56. Umbach, A.L.; Fiorani, F.; Siedow, J.N. Characterization of transformed Arabidopsis with altered oxidase levels and analysis of effect on reactive oxygen species in tissue. Plant Physiol. 2005, 139, 1806-1820. [CrossRef] [PubMed]

57. Giraud, E.; Ho, L.H.; Clifton, R.; Carroll, A.; Estavillo, G.; Tan, Y.F.; Howell, K.A.; Ivanova, A.; Pogson, B.J.; Millar, A.H.; et al. The absence of alternative oxidase 1a in Arabidopsis results in acute sensitivity to combined light and drought stress. Plant Physiol. 2008, 147, 595-610. [CrossRef] [PubMed]

58. Liu, Y.J.; Norberg, F.E.B.; Szilágyi, A.; De Paepe, R.; Åkerlund, H.E.; Rasmusson, A.G. The mitochondrial external NADPH dehydrogenase modulates the leaf NADPH/NADP ${ }^{+}$ratio in transgenic Nicotiana sylvestris. Plant Cell Physiol. 2008, 49, 251-263. [CrossRef] [PubMed]

59. Smith, C.; Barthet, M.; Melino, V.; Smith, P.; Day, D.; Soole, K. Alterations in the mitochondrial alternative $\mathrm{NAD}(\mathrm{P}) \mathrm{H}$ dehydrogenase NDB4 lead to changes in mitochondrial electron transport chain composition, plant growth and response to oxidative stress. Plant Cell Physiol. 2011, 52, 1222-1237. [CrossRef] [PubMed]

60. Foyer, C.H.; Noctor, G. Redox sensing and signalling associated with reactive oxygen in chloroplasts, peroxisomes and mitochondria. Physiol. Plant. 2003, 119, 355-364. [CrossRef]

61. Huang, S.; Van Aken, O.; Schwarzländer, M.; Belt, K.; Millar, A.H. The roles of mitochondrial reactive oxygen species in cellular signaling and stress response in plants. Plant Physiol. 2016, 171, 1551-1559. [CrossRef] [PubMed]

62. Liu, Y.J.; Nunes-Nesi, A.; Wallström, S.V.; Lager, I.; Michalecka, A.M.; Norberg, F.E.; Widell, S.; Fredlund, K.M.; Fernie, A.R.; Rasmusson, A.G. A redox-mediated modulation of stem bolting in transgenic Nicotiana sylvestris differentially expressing the external mitochondrial NADPH dehydrogenase. Plant Physiol. 2009, 150, 1248-1259. [CrossRef] [PubMed]

63. Zechmann, B.; Stumpe, M.; Mauch, F. Immunocytochemical determination of the subcellular distribution of ascorbate in plants. Planta 2011, 233, 1-12. [CrossRef] [PubMed]

64. Zechmann, B. Compartment-specific importance of glutathione during abiotic and biotic stress. Front. Plant Sci. 2014, 5, 566. [CrossRef] [PubMed] 
65. Queval, G.; Thominet, D.; Vanacker, H.; Miginiac-Maslow, M.; Gakière, B.; Noctor, G. $\mathrm{H}_{2} \mathrm{O}_{2}$-activated up-regulation of glutathione in Arabidopsis involves induction of genes encoding enzymes involved in cysteine synthesis in the chloroplast. Mol. Plant 2009, 2, 344-356. [CrossRef] [PubMed]

66. Gill, S.S.; Anjum, N.A.; Hasanuzzaman, M.; Gill, R.; Trivedi, D.K.; Ahmad, I.; Pereira, E.; Tuteja, N. Glutathione and glutathione reductase: A boon in disguise for plant abiotic stress defense operations. Plant Physiol. Biochem. 2013, 70, 204-212. [CrossRef] [PubMed]

67. Marty, L.; Siala, W.; Schwarzländer, M.; Fricker, M.D.; Wirtz, M.; Sweetlove, L.J.; Meyer, Y.; Meyer, A.J.; Reichheld, J.P.; Hell, R. The NADPH-dependent thioredoxin system constitutes a functional backup for cytosolic glutathione reductase in Arabidopsis. Proc. Natl. Acad. Sci. USA 2009, 106, 9109-9114. [CrossRef] [PubMed]

68. Zagorchev, L.; Seal, C.E.; Kranner, I.; Odjakova, M. A central role for thiols in plant tolerance to abiotic stress. Int. J. Mol. Sci. 2013, 14, 7405-7432. [CrossRef] [PubMed]

69. Zaffagnini, M.; Bedhomme, M.; Marchand, C.H.; Couturier, J.; Gao, X.H.; Rouhier, N.; Trost, P.; Lemaire, S.D. Glutaredoxin S12: Unique properties for redox signaling. Antioxid. Redox Sign. 2012, 16, 17-32. [CrossRef] [PubMed]

70. Patterson, K.; Walters, L.A.; Cooper, A.M.; Olvera, J.G.; Rosas, M.A.; Rasmusson, A.G.; Escobar, M.A. Nitrate-regulated glutaredoxins control Arabidopsis primary root growth. Plant Physiol. 2016, 170, 989-999. [CrossRef] [PubMed]

71. Dietz, K.-J. Redox signal integration: From stimulus to networks and genes. Physiol. Plant. 2008, 133, 459-468. [CrossRef] [PubMed]

72. Baier, M.; Dietz, K.-J. Protective function of chloroplast 2-cysteine peroxiredoxin in photosynthesis. Evidence from transgenic Arabidopsis. Plant Physiol. 1999, 119, 1407-1414. [CrossRef] [PubMed]

73. König, J.; Baier, M.; Horling, F.; Kahmann, U.; Harris, G.; Schürmann, P.; Dietz, K.-J. The plant-specific function of 2-Cys peroxiredoxin-mediated detoxification of peroxides in the redox-hierarchy of photosynthetic electron flux. Proc. Natl. Acad. Sci. USA 2002, 99, 5738-5743. [CrossRef] [PubMed]

74. Petersson, U.A.; Kieselbach, T.; García-Cerdán, J.G.; Schröder, W.P. The Prx Q protein of Arabidopsis thaliana is a member of the luminal chloroplast proteome. FEBS Lett. 2006, 580, 1873-3468. [CrossRef] [PubMed]

75. König, J.; Galliardt, H.; Jütte, P.; Schäper, S.; Dittmann, L.; Dietz, K.-J. The conformational bases for the two functionalities of 2-cysteine peroxiredoxins as peroxidase and chaperone. J. Exp. Bot. 2013, 64, 3483-3497. [CrossRef] [PubMed]

76. Muthuramalingam, M.; Seidel, T.; Laxa, M.; Nunes de Miranda, S.M.; Gartner, F.; Stroher, E.; Kandlbinder, A.; Dietz, K.-J. Multiple redox and non-redox interactions define 2-Cys peroxiredoxin as a regulatory hub in the chloroplast. Mol. Plant 2009, 2, 1273-1288. [CrossRef] [PubMed]

77. Dietz, K.-J.; Horling, F.; König, J.; Baier, M. The function of the chloroplast 2-cysteine peroxiredoxin in peroxide detoxification and its regulation, J. Exp. Bot. 2002, 53, 1321-1329. [CrossRef]

78. Lamkemeyer, P.; Laxa, M.; Collin, V.; Li, W.; Finkemeier, I.; Schöttler, M.A.; Holtkamp, V.; Tognetti, V.B.; Issakidis-Bourguet, E.; Kandlbinder, A.; et al. Peroxiredoxin Q of Arabidopsis thaliana is attached to the thylakoids and functions in context of photosynthesis. Plant J. 2006, 45, 968-981. [CrossRef] [PubMed]

79. Horling, F.; Lamkemeyer, P.; König, J.; Finkemeier, I.; Kandlbinder, A.; Baier, M.; Dietz, K.-J. Divergent light-, ascorbate-, and oxidative stress-dependent regulation of expression of the peroxiredoxin gene family in Arabidopsis. Plant Physiol. 2003, 131, 317-325. [CrossRef] [PubMed]

80. Rouhier, N.; Gelhaye, E.; Gualberto, J.M.; Jordy, M.-N.; De Fay, E.; Hirasawa, M.; Duplessis, S.; Lemaire, S.D.; Frey, P.; Martin, F.; et al. Poplar Peroxiredoxin Q. A thioredoxin-linked chloroplast antioxidant functional in pathogen defense. Plant Physiol. 2004, 134, 1027-1038. [CrossRef] [PubMed]

81. Yoshida, K.; Hisabori, T. Two distinct redox cascades cooperatively regulate chloroplast functions and sustain plant viability. Proc. Natl. Acad. Sci. USA 2016, 113, 3967-3976. [CrossRef] [PubMed]

82. Pérez-Ruiz, J.M.; Naranjo, B.; Ojeda, V.; Guinea, M.; Cejudo, F.J. NTRC-dependent redox balance of 2-Cys peroxiredoxins is needed for optimal function of the photosynthetic apparatus. Proc. Natl. Acad. Sci. USA 2017, 114, 12069-12074. [CrossRef] [PubMed]

83. Finkemeier, I.; Goodman, M.; Lamkemeyer, P.; Kandlbinder, A.; Sweetlove, L.J.; Dietz, K.J. The mitochondrial type II peroxiredoxin $\mathrm{F}$ is essential for redox homeostasis and root growth of Arabidopsis thaliana under stress. J. Biol. Chem. 2005, 280, 12168-12180. [CrossRef] [PubMed] 
84. Horling, F.; König, J.; Dietz, K.-J. Type II peroxiredoxin C, a member of the peroxiredoxin family of Arabidopsis thaliana: Its expression and activity in comparison with other peroxiredoxins. Plant Physiol. Biochem. 2002, 40, 491-499. [CrossRef]

85. Murashige, T.; Skoog, F. A revised medium for rapid growth and bioassay with tobacco tissue cultures. Physiol. Plant. 1962, 15, 473-497. [CrossRef]

86. Florez-Sarasa, I.; Ostaszewska, M.; Galle, A.; Flexas, J.; Rychter, A.M.; Ribas-Carbó, M. Changes of alternative oxidase activity, capacity and protein content in leaves of Cucumis sativus wild-type and MSC16 mutant grown under different light intensities. Physiol. Plant. 2009, 137, 419-426. [CrossRef] [PubMed]

87. Escobar, M.A.; Franklin, K.A.; Svensson, A.S.; Salter, M.G.; Whitelam, G.C.; Rasmusson, A.G. Light regulation of the Arabidopsis respiratory chain. Multiple discrete photoreceptor responses contribute to induction of type II NAD(P)H dehydrogenase genes. Plant Physiol. 2004, 136, 2710-2721. [CrossRef] [PubMed]

88. Podgórska, A.; Ostaszewska, M.; Gardeström, P.; Rasmusson, A.G.; Szal, B. In comparison with nitrate nutrition, ammonium nutrition increases growth of the frostbite1 Arabidopsis mutant. Plant Cell Environ. 2015, 38, 224-237. [CrossRef] [PubMed]

89. Czechowski, T.; Stitt, M.; Altmann, T.; Udvardi, M.K.; Scheible, W.R. Genome-wide identification and testing of superior reference genes for transcript normalization in Arabidopsis. Plant Physiol. 2005, 139, 5-17. [CrossRef] [PubMed]

90. Pfaffl, M.W. A new mathematical model for relative quantification in real-time RT-PCR. Nucleic Acids Res. 2001, 29, e45. [CrossRef] [PubMed]

91. Szal, B.; Dąbrowska, Z.; Malmberg, G.; Gardeström, P.; Rychter, A.M. Changes in energy status of leaf cells as the consequence of mitochondrial genome rearrangement. Planta 2008, 227, 697-706. [CrossRef] [PubMed]

92. Veljović-Jovanović, S.; Noctor, G.; Foyer, C.H. Are leaf hydrogen peroxide concentrations commonly overestimated? The potential influence of artefactual interference by tissue phenolics and ascorbate. Plant Physiol. Biochem. 2002, 40, 501-507. [CrossRef]

93. Okamura, M. An improved method for determination of L-ascorbic acid and L-dehydroascorbic acid in blood plasma. Clin. Chim. Acta 1980, 103, 259-268. [CrossRef] [PubMed]

94. Brehe, J.E.; Burch, H.B. Enzymatic assay for glutathione. Anal. Biochem. 1976, 74, 189-197. [CrossRef]

95. Hodges, D.; DeLong, J.; Forney, C.F.; Prange, R.K. Improving the thiobarbituric acid-reactive-substances assay for estimating lipid peroxidation in plant tissues containing anthocyanin and other interfering compounds. Planta 1999, 207, 604-611. [CrossRef]

96. Ostaszewska-Bugajska, M.; Rychter, A.M.; Juszczuk, I.M. Antioxidative and proteolytic systems protect mitochondria from oxidative damage in S-deficient Arabidopsis thaliana. J. Plant Physiol. 2015, 186-187, 25-38. [CrossRef] [PubMed]

97. Bradford, M.M. A rapid and sensitive method for quantification of microgram quantities of protein utilizing the principle of protein-dye binding. Anal. Biochem. 1976, 72, 248-254. [CrossRef]

98. Kuznetsov, A.V.; Kehrer, I.; Kozlov, A.V.; Haller, M.; Redl, H.; Hermann, M.; Grimm, M.; Troppmair, J. Mitochondrial ROS production under cellular stress: Comparison of different detection methods. Anal. Bioanal. Chem. 2011, 400, 2383-2390. [CrossRef] [PubMed]

99. Hill, B.G.; Ramana, K.V.; Cai, J.; Bhatnagar, A.; Srivastava, S.K. Measurement and identification of S-glutathiolated proteins. In Methods in Enzymology; Cadenas, E., Packer, L., Eds.; Academic Press: Cambridge, MA, USA, 2010; Volume 473, pp. 179-197.

100. Podgórska, A.; Burian, M.; Rychter, A.M.; Rasmusson, A.G.; Szal, B. Short-term ammonium supply induces cellular defence to prevent oxidative stress in Arabidopsis leaves. Physiol. Plant. 2017, 160, 65-83. [CrossRef] [PubMed]

101. Hossain, M.A.; Asada, K. Inactivation of ascorbate peroxidase in spinach chloroplasts on dark addition of hydrogen peroxide: Its protection by ascorbate. Plant Cell Physiol. 1984, 25, 85-92. [CrossRef]

102. Kuźniak, E.; Skłodowska, M. The effect of Botrytis cinerea infection on ascorbate-glutathione cycle in tomato leaves. Plant Sci. 1999, 148, 69-76. [CrossRef]

103. Sehmer, L.; Fontaine, V.; Antoni, F.; Dizengremel, P. Effects of ozone and elevated atmospheric carbon dioxide on carbohydrate metabolism of spruce needles. Catabolic and detoxification pathways. Physiol. Plant. 1998, 102, 605-611. [CrossRef] 
104. Gutzat, R.; Mittelsten Scheid, O. Epigenetic responses to stress: Triple defense? Curr. Opin. Plant. Biol. 2012, 15, 568-573. [CrossRef] [PubMed]

105. Foyer, C.H.; Rasool, B.; Davey, J.W.; Hancock, R.D. Cross-tolerance to biotic and abiotic stresses in plants: A focus on resistance to aphid infestation. J. Exp. Bot. 2016, 67, 2025-2037. [CrossRef] [PubMed]

(C) 2018 by the authors. Licensee MDPI, Basel, Switzerland. This article is an open access article distributed under the terms and conditions of the Creative Commons Attribution (CC BY) license (http:// creativecommons.org/licenses/by/4.0/). 